\title{
The Management of Expenditures and Revenue by Alexander the Great During his Expedition to the Boundless Asia
}

\author{
Dr. Ioannis N. Kallianiotis \\ Economics/Finance Department, The Arthur J. Kania School of Management, \\ University of Scranton, US \\ ioannis.kallianiotis@scranton.edu
}

\begin{abstract}
The philosophy of Oeconomicos (Economics) and the basic practical economic policy were developed by Xenophon in Ancient Greece. Alexander the Great was living a little later in the $4^{\text {th }}$ century B.C. and we know him as a great Greek (Hellen) king, civilizer, and "forerunner"; but, he was at the same time, an excellent economist because he had to manage the economy of his enormous campaign from North Greece to India, to exercise an efficient and effective public policy for his vast Empire, and to satisfy all the citizens as a Hellenic civilizer. Also, "he desired not pleasure or wealth, but only excellence and glory", which was the teaching of the moral and ethical Greek philosophy. Alexander was grateful to gods for his Greek descent and had all these Hellenic values that made him one of the most important persons in human history. As a student of the greatest of philosophers Aristotle, he has shown outstanding management capabilities, with rates of salaries, health and welfare systems, advanced social policies, building projects, supplies, transports, reforms of the tax system, loans, founding of new cities, even controlling financial scandals and other information useful for our policy makers, today. We will measure his budgets by using the weights of gold and silver coins and determine and compare prices by taking these information from different ancient historians. Alexander's moral leadership and ethical economic policy with its surpluses is very useful for all scholars. Also, it is mentioned the history and the role of this extraordinary man and the contribution of the Greek civilization and language in God's plan, for His revolted and deluded creation and humanity to be in a position to understand and accept His revelation, which Greeks were expecting from their oracles since $5^{\text {th }}$ century B.C.
\end{abstract}

Keywords: Role of Economics: Role of Economists, History of Economic Thought, Monetary Policy, Fiscal Policy, General: Economic History, Development of the Discipline: Historiographical and Sources and Methods

\section{INTRODUCTION}

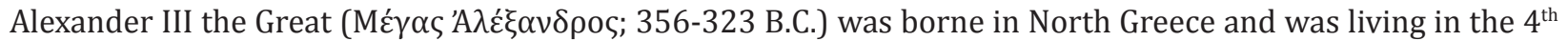
century B.C. We know him as a great Greek (Hellen) general and king, but he was at the same time, an excellent

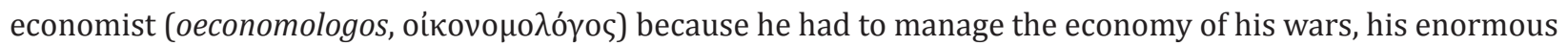
campaign from North Greece (Macedonia) ${ }^{1}$ to India (Hindus River), and to exercise an efficient and effective public policy (revenue, spending, and surpluses) for his vast Empire and to satisfy all the citizens as a civilizer and not as a conqueror. His role, as it was proved later, was a divine one; he was a "social forerunner". At a point Alexander said that “...I am grateful to gods that I was borne Hellen....' ${ }^{2}$ He had the consciousness of his historic descent and invitation ("call from God"). Of course, as a student of the greatest of philosophers (panepistimon,

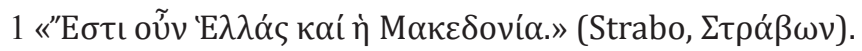

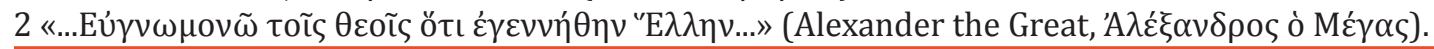




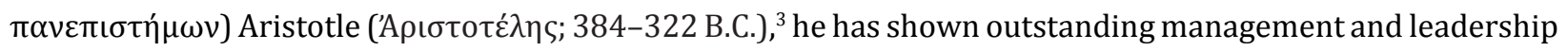
capabilities. His military budgets contained more or less what budgets of states comprised (and were directly related to the latter); like, rates of salaries and wages, health and social welfare programs, building construction projects, supplies of military material and food, transports, acquisitions and maintenance of military equipment, reforms of the tax system, donations and debt financing, royal lands apportionment, support of veterans and their families, building of cities and infrastructures, even controlling financial scandals and we can extract many other information from these Hellenic studies useful for our leaders and policy makers, today (after 2,350 years), and for economic historians and numismatics.

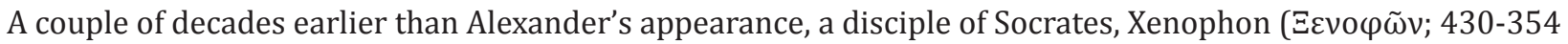

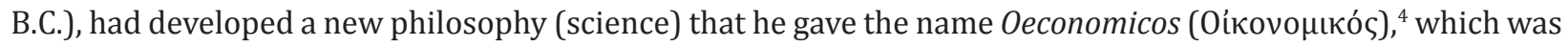
misspelled in $18^{\text {th }}$ century A.D. in West Europe and was written as Economics; but its creator was Xenophon and for this reason, he is the "Father of Economics". The meaning of this discipline is "the management of household"

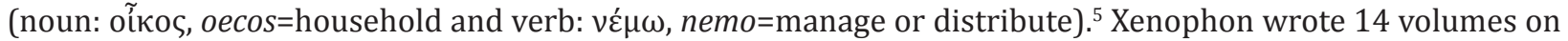
the management of the different sectors of the economy. One of the volumes was Ways and Means (Пópoเท̂ $\pi \varepsilon p i$

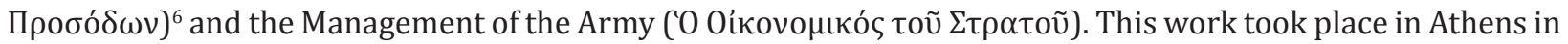
the $5^{\text {th }}$ century B.C. (the Golden Century of Pericles), ${ }^{7}$ and continued in the first half of the $4^{\text {th }}$ century A.D.; but even from the Homeric period, we see good "economists" and their ability to manage effectively their societies. We also see a fiscal and royal redistribution economic system of that period. Then, we use the historic evidence to calculate expenditures and revenues and leave the interpretation of the economic conditions for a future systematic analysis.

In addition to economics, numismatics, ${ }^{8}$ and economic policy, we can see many political, military, cultural and futuristic events during that period and the following Hellenistic era. Economic history is necessary for all social scientists (especially economists) because this past knowledge can help us to deal with the current complex global economic, social, and political problems. The contribution of Alexander the Great, with the spreading of the Greek civilization, and the learning of the most advanced language, the Greek language by the known world was beyond a human plan and offering. It was a divine plan for the preparation of the world to accept the unique event in human history that followed three hundred years later, the coming of the Son of God (the revelation of the highest value, the Truth) that Socrates and other moral philosophers were expected five centuries ago and

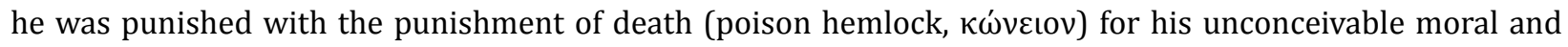
ethical philosophical conception of "the Unknown God".

3 According to theEncyclopædia Britannic. "Aristotle was the first genuine scientist in history ... [and] every scientist is in his debt."

4 The Oeconomicus (Oíкоvонккós) can actually be seen as a treatise on success in leading both an army and a state. Cicero translated the Oeconomicus into Latin, and the work gained popularity during the Renaissance in a number of translations. Adam Smith has taken many ideas from Oeconomicus, but he "forgot" to give reference to Xenophon. See, Marchant and Todd (1997, p. 408).

5 See, Kallianiotis (2013a).

6 See, Whitehead (1977).

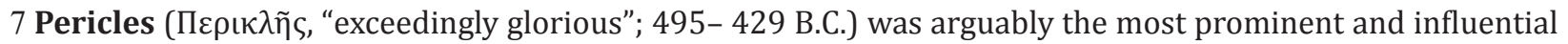
Greek statesman, orator, and general of Athens during the Golden Age (480-404 B.C.) specifically the time between the Persian (499-449 B.C.) and Peloponnesian (431-404 B.C.) wars. See, Thucydides, 2.65. Also, Blois de, Lukas (1997). Unfortunately, there are no populist leaders in our days.

8 See, Kallianiotis (2015b).

10 See, Ancient Greek prophesies regarding the True, but Unknown at that time, God. http://www.impantokratoros.gr/neopaganismos_filosofoi.el.aspx. See also, Kallianiotis (2016a). 


\section{AleXANDER's EXPEDition to ASIA AND India AND ITS EXPENDITURES}

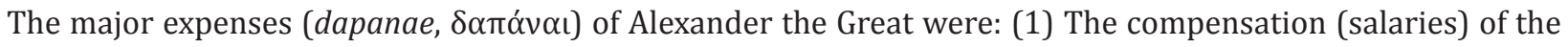
army. (2) Food and other provisioning of the huge army personnel. (3) The support of veterans and their families. (4) Maintenance cost of armament, equipment, and siege machines. (5) The development and creation of the navy. (6) The healthcare of his personnel and soldiers. (7) Transportation of the soldiers and equipment. (8) Feasts and social events. The most costly expenditures were the payroll of the army and especially, during the expedition to the remote India (an amount of 1,074,579,600 Drs or $\$ 164,253,594.1$ ), as Table 2, 1a \& 2 shows. His army was comprised, by Greek-Macedonians, who were serving their country, by allies from the Greek cities

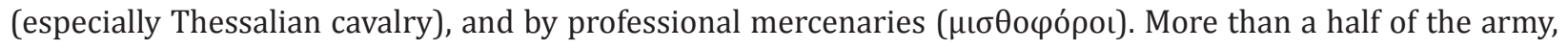
for his planned invasion to punish Persia and Hellenize Asia, came from outside the borders of Macedonia, from all over the Greek world and the nearby barbarian tribes. The focus, here, is not only economic, but on history, language, and social studies; emphasizing the military and political events.

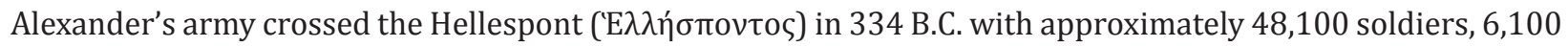
cavalry and a fleet of 120 ships with crews numbering 38,000, ${ }^{10}$ drawn from Macedon (M $\alpha \kappa \varepsilon \delta o v i ́ \alpha$ ) and various

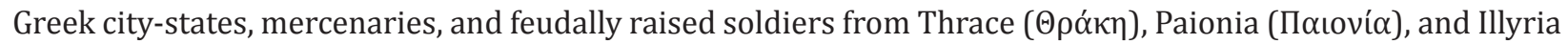
('I $\lambda \lambda u$ uí $\alpha$ or 'I $\lambda \lambda u$ uís). ${ }^{11}$ Ship-building wood from royal forests were also available. A letter from Philippoi to

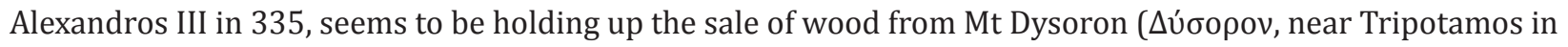
Kilkis). The control of resources (like timber, etc.) was not only as a commodity for the market, but as a strategic resource to be doled out as a philanthropy. ${ }^{12}$ Firewood and charcoal were necessary for houses, for baths, and gymnasia, too. Wood was also transported long distances. Macedonia, Chalkidiki, Lebanon, and other places had big forests and were supplying wood. Alexander showed his intent to conquer the entirety of the Persian Empire and punish them for their invasions of Greece by throwing a spear into Asian soil and saying, he accepted Asia as a gift from the gods. This also showed Alexander's eagerness to fight and the bravery of his character, in contrast to his father's preference for diplomacy; but undoubtedly, it was his destiny ( $\pi \varepsilon \pi \rho \omega \mu \varepsilon ́ v o v)$, too.

Different historical sources give the salary of a common soldier as 1-2 drachmas per day. Decadarches (dekaneis,

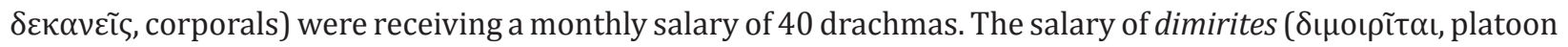
leader or troop commander) was twice the salary of corporals (80 Drs), and the salary of cavalries (horsemen) was twice the salary of the infantries, 200 Drs (foot soldiers). According to Diodorus, cavalries (i $\pi \pi \varepsilon i$ s) were receiving 300 drachmas per month ${ }^{13}$ and the carriers of Macedonian phalanx ( $\left.\varphi \alpha \lambda \alpha \gamma \gamma \tilde{\tau} \tau \alpha\right)$ ) were receiving 100 drachmas. ${ }^{14}$ For the professional mercenaries, there were extra economic incentives, as Kostopoulos (2012) mentions.

Calculating the total expenditures in 334 B.C., they were enormous because of the size of his army that passed the Dardanelles $(\Delta \alpha \rho \delta \alpha v \varepsilon \dot{\varepsilon} \lambda \iota \alpha)$ and went to Asia Minor. This military force was 35,000 men, plus another 10,000 people under Parmenion ( $\Pi \alpha \rho \mu \varepsilon v i ́ \omega v$ ), who had passed two years earlier in 336 B.C. and an extra army 10 A cost of 31,578,000 Drs (38,000 sailors x 832 Drs/annum). See, Kallianiotis (2016b, Table 2b). See, Roisman

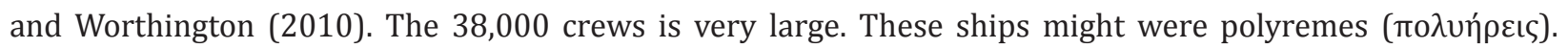
Triremes ( $\tau$ เท́ $\rho \varepsilon เ \varsigma)$ had 200 crews of which 170 were rowers.

11 See, Arrian (1976).

12 See, Davies (2011).

13 This salary of 300 Drs seems very high. The most probable was twice the salary of the phalanx ( 2 x $100 \mathrm{Drs}$ $=200$ Drs). See, Kallianiotis (2016b, Table 2a).

14 The wages were from 1 Dr to 6.66 Drs (from $\$ 2.868$ to $\$ 19.100$ ) per day. See, Kallianiotis (2015b, Table 3a). 
of 12,000 men that Alexander was keeping in Macedonia. This army was a total of 57,000 men and their salaries are estimated to be 4,000-5,000 talents $(\tau \alpha \dot{\alpha} \lambda \alpha \nu \tau \alpha)^{15}$ during the first year of the expedition. The cost in 336-335 B.C. was $23,144,000$ Drs $(\$ 66,376,992)$ and the cost in 334 B.C. was $61,560,000$ Drs $(\$ 176,554,080) .{ }^{16}$ The cost in the consecutive years increased to 7,000 talents [without including fleet ( $\sigma$ tó $\lambda_{0 \varsigma}$ ) wages] because Alexander hired more mercenaries from the Greek cities in Asia Minor and he needed to put guards to the areas that he conquered. This cost is measured as $73,578,000$ Drs $(\$ 211,021,704) \cdot{ }^{17}$

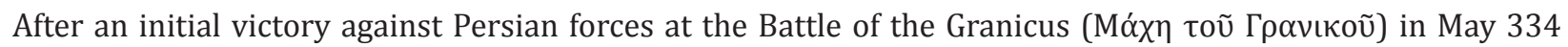
B.C., Alexander accepted the surrender of the Persian provincial capital and treasury of Sardis ( $\Sigma \alpha \dot{\alpha} \rho \delta \varepsilon \varsigma$ ); he

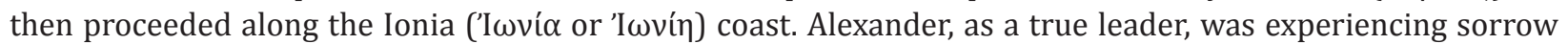
for his men, who fell in battle and those who died were rewarded generously: "To the relatives of his fallen, Alexander granted immunity from taxation and public service." Whether it was his own warriors or the Persian forces opposing him, Alexander chose to respect those who died. He even went so far to set up statues to honor and respect these people. Though this did not directly influence the culture of the Persians, they did not feel the need to begin a rebellion as their men and rulers were treated with proper respect. ${ }^{18}$ At Halicarnassus

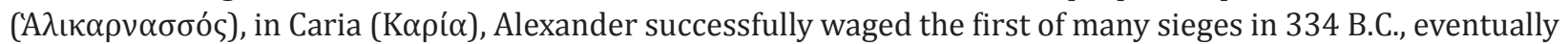

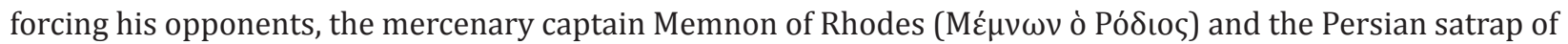

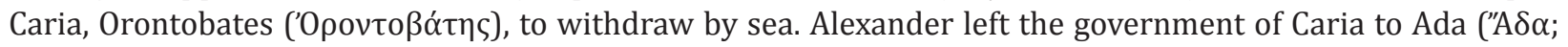
377-326 B.C.), who adopted Alexander.

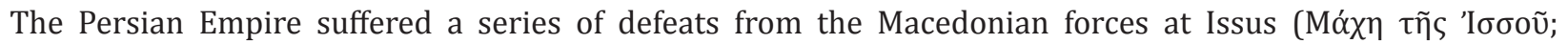

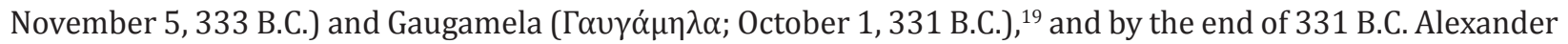
had advanced to Babylon $(B \alpha \beta v \lambda \omega \dot{v})$ and Susa $(\Sigma o v \tilde{\sigma \alpha})$. A Royal Road connected Susa (the first Iranian capital

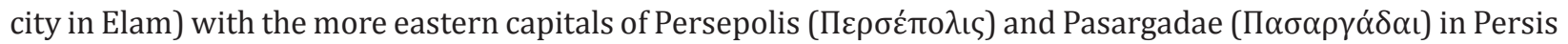

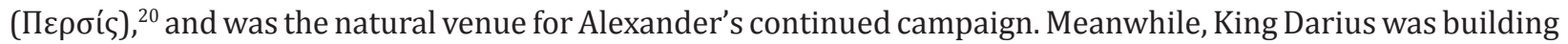

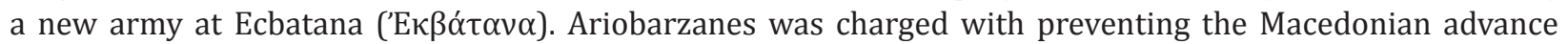
into Persis, and to this effect he relied heavily on the terrain Alexander needed to pass through. According to historian Arrian (Anabasis 3.18.2), Ariobarzanes had a force of 40,000 infantry and 700 cavalry, who faced a Macedonian force of over 10,000.

We calculate the annual cost from 333-328 B.C. and it was 73,578,000 Drs $(\$ 211,021,704)$. The period covers

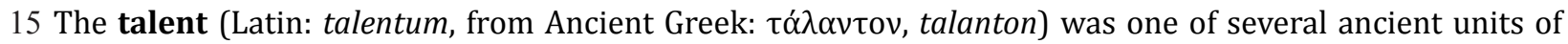
mass, a commercial weight, as well as corresponding units of value equivalent to these masses of a precious

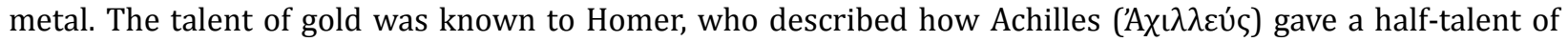

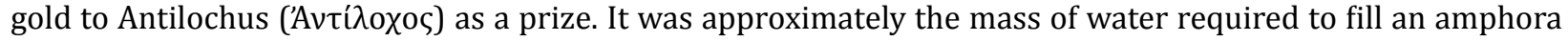

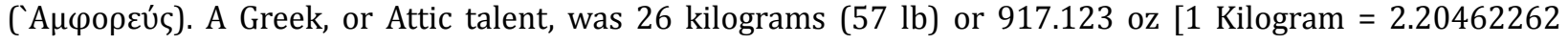
Pounds $=35.2739619$ Ounces $]$ or 6,000 Drachmas [ $1 \mathrm{Dr}=0.15285 \mathrm{oz}$ Gold or $1 \mathrm{oz}$ of Gold $=6.54236$ Drs.]. The value in dollars of an Attic talent of $26 \mathrm{kgs}$ of gold in today's $\mathbf{6 / 3 0 / 2 0 1 6 )}$ price of $(\$ 1,320.50 / \mathbf{o z})$ will be $\$ 1,211,060.922$ and the exchange rate between dollars and gold drachmas could be: $\mathrm{e}_{1}=\$ 1,320.50 / 6.54220$ Drs $=201.843 \$ / D r$ (a Greek Attic gold Drachma had a value of $\$ 201.843$ in today' dollar value with respect the gold). The price of silver on June 30, 2016 was $\$ \mathbf{1 8 . 7 6 / o z}$; then, the value in dollars of an Attic silver talent will be $\$ 17,205.227$ and the exchange rate between dollar and silver Drachmas: $e_{2}=2.868 \$ / D r$ (Table 1). See, Engen (2004). Also, Torr (1906). Further, we can see their measures as follows: http://en.wikipedia.org/wiki/ Talent_(measurement) and http://en.wikipedia.org/wiki/Attic_talent

16 See, Kallianiotis [2016b, Table 2b (i) and (ii)].

17 See, Kallianiotis [2016b, Table 2b (iii)] for details.

18 See, Arrian (1976).

19 See, https://www.youtube.com/watch?v=_QEG01V9d-Q

20 The Old Persian word was Pârsâ. See, Nelson Frye (1984).

Volume 2016

Page 4 
six years; thus, the cost was 73,578,000 x $6=441,468,000$ Drs $(\$ 1,266,130,224) .{ }^{21}$ Also, from 333 B.C. to 330 B.C., Alexander's bonuses to his soldiers were $96,000,000$ Drs $(\$ 275,328,000)$. The total expenditures in Asia (336-328 B.C.) are calculated to be $622,172,000$ Drs or $\$ 1,784,389,296$ (Table 2, 1). After the occupation of Susa and Persepolis (330 B.C.) and the acquisition of the Darius' Treasure, the cost of army wages skyrocketed. This is a little difficult to be explained; it seems that wages went up, due to an excess supply of money (wealth) or due to the generosity of Alexander towards to his soldiers. The most probable is that Darius wealth caused inflation. The cost was 7,000 talents/annum and we assume that it became 8,000 talents/annum $(48,000,000$ Drs/annum or $\$ 137,664,000$ ). The army was 79,850 men, which makes the cost $601 \mathrm{Drs} / \mathrm{man} /$ annum. From 526 Drs, it reached 601 Drs; an increase in salary by $14.259 \%$. Then, after 328 B.C., Alexander continued with the expedition to India, for which Alexander gathered an army of 140,000 men and his expenditures also went up. ${ }^{22}$ This cost is, now, 84,140,000 Drs (140,000 men x 601 Drs/man/annum) or $\$ 241,313,520$. He constructed and used also a fleet of 150 ships for the same expedition with 3,000-5,000 sailors. ${ }^{23}$ The cost/trireme is estimated of 20,384 Drs; then, total cost: 150 ships x 20,384 Drs $=3,057,600$ Drs or $\$ 8,769,196.8$. In 327 B.C., the total cost of soldiers, ships, and sailors was $112,127,600$ Drs or $\$ 321,581,956.8 .^{24}$ Thus, the total cost for the 5 years expedition in India (327-323 B.C.) was $548,407,600$ Drs or $\$ 1,572,832,997$. (Table 2, 2).

Also, huge were the expenses for maintenance and new acquisitions of military equipment and material. The average army was 130,000 men x 12 Drs/man/annum $=1,560,000$ Drs/annum or $\$ 4,474,080$, which make up for the 13 years a total material cost of $20,280,000$ Drs or $\$ 58,163,040$. His army was followed by engineers,

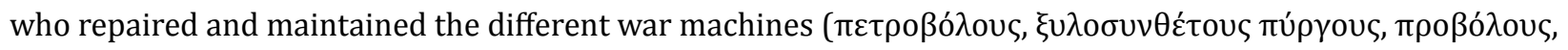
$\dot{\varepsilon} \lambda \varepsilon \pi$ ó $\lambda \varepsilon เ \varsigma, \kappa \rho ı$ tents, beds, useful tools, and other constructions. Assuming 13,000 people x 923 Drs (skilled worker) $=11,999,000$ Drs/annum $(\$ 34,413,132)$ and for the 13 years of campaign make up a cost of $155,987,000$ Drs or $\$ 447,370,716 .{ }^{25} \mathrm{~A}$ total cost for military equipment and constructions of $176,267,000$ Drs or $\$ 505,533,756$ (Table 2,3). Another major expense was the food and transportation of the soldiers and of their families (wives and children). The food and transportation for the soldiers and their families were: 200,000 people x 0.5 Drs/ day $\times 360$ days $=36,000,000$ Drs/annum $(\$ 103,248,000)$ and for the 13 years of the expedition the cost was $468,000,000$ Drs or $\$ 1,342,224,000$. Medical services were also expensive because he had doctors, herbalists, botanists, pharmacists, nurses, and other health personnel, who follow the expedition. The medical services had a cost of $1,846,000$ Drs/annum or $23,998,000$ Drs $(\$ 68,826,264)$ for the entire campaign. The cost of medicine was 600,000 Drs x 13 years, equal to $7,800,000$ Drs $(\$ 22,370,400)$. A total cost of 31,798,000 Drs or $\$ 91,196,664$. Diodorus Siculus mentions that for his expedition to India, Alexander spent for medicines 100 talents per annum $(=600,000$ Drs $=91,712.28$ ozs or $\$ 1,720,522.373$ for silver talents or $\$ 121,106,065.7$ for gold talents). (Table 2, 5).

In addition, other expenses were the indemnities to the parents and families of the soldiers, who fell in the

21 See, Kallianiotis (2016b, Table 2b).

22 If the annual cost went up to 8,000 talents or $48,000,000$ Drs/annum or $\$ 137,664,000$, the cost of $(140,000)$ soldiers was: $117,894,736.8$ Drs or $\$ 338,122,105.1$, if there were silver talents or $\$ 23,796,227,360$, if there were gold.

23 The cost of sailors was between $2,526,315.789$ Drs $(\$ 509,919,157.8$ gold or $\$ 7,245,473.683$ silver $)$ and $4,210,526.316$ Drs $(\$ 849,865,263.2$ gold or $\$ 12,075,789.47$ silver).

24 See, Kallianiotis (2016b, Table 2b, B').

25 See, Kallianiotis (2016b, Table 2b, 3). 
different battles. The indemnities to families for the fallen soldiers were $156,000,000$ Drs $(\$ 447,408,000)$; the salaries to the orphan children were $164,112,000$ Drs $(\$ 470,673,216)$; and the paid off of soldiers' debts were $17,000,000$ Drs $(\$ 48,756,000)$; a total of $337,112,000$ Drs $(\$ 966,837,216)$ and a grand total of $437,447,000$

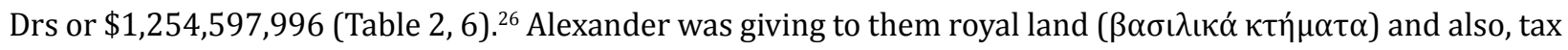

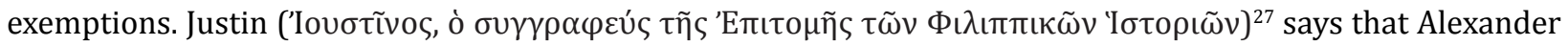
was continuing to pay the orphans of the killed soldiers the salary of their fathers. Another expense was the feasts and celebrations for boosting the confidence of the people and the morale of the army and these costs were enormous, too, due to the huge army and their families. The cost for the feasts is estimated to be 52,000,000 Drs, plus 1,000,000 Drs, plus 100,000 Drs, plus 407,050 Drs; a total of 53,507,050 Drs or $\$ 153,458,219.4$. (Table $2,7){ }^{28}$ Also, he had to pay cooks, waiters, bakers, wheat growers, and for many other professions that are unknown, today. The cost of cooks was $173,420,000$ Drs $(\$ 497,368,560)$. In addition, he had to cover the cost

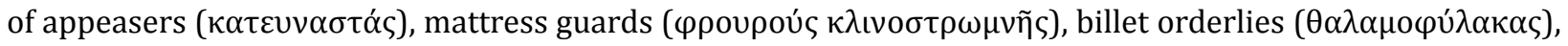
who were guarded Alexander and his generals during their sleep at nights.

Further, royal meals were also a big expense with the cost of food, its preparations, and all the required personnel. ${ }^{29}$ Their annual cost was $36,000,000$ Drs $(\$ 103,248,000)$; a total of $468,000,000$ Drs $(\$ 1,342,224,000)$, for the 13 years, even though that Alexander did not care for any luxurious life. ${ }^{30}$ Alexander was utterly generous regarding the rewards as bonuses to men, who distinguished themselves in battles and sieges. According to

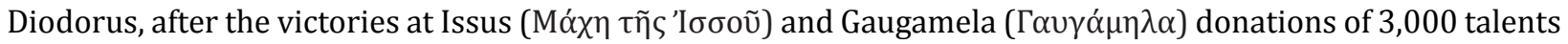
$(18,000,000$ Drs or $2,751,368.4$ ozs or $\$ 51,624,000)$ were made to his soldiers, ${ }^{31}$ while for the conquest of

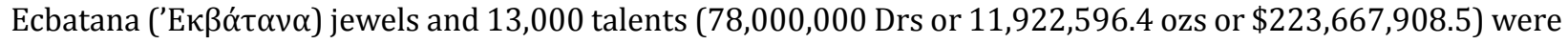

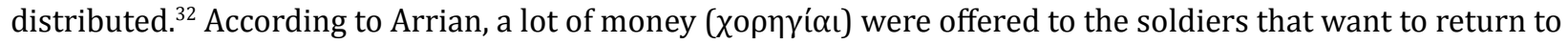
their native country. Greek allies, who wished to repatriate were given to them 2,000 talents $(12,000,000$ Drs or $1,834,245.6$ ozs or $\$ 34,416,000$ ) as salaries and expenses for returning home, while those who decided to stay after all received 3 talents $(18,000$ Drs or $2,751.368$ ozs or $\$ 51,624)$ each soldier. ${ }^{33}$ Alexander was also generous towards veterans. According to Arrian, Macedonians who became unable for war, due to old age or illness, received their salary and one extra talent [6,000 Drs or 917.123 ozs or $\$ 17,208$ (silver)], as well as the costs of the journey, the travel expenses to return home. ${ }^{34}$

Lastly, as a gesture of thanks, Alexander paid off the debts of his soldiers $(17,000,000$ Drs or $\$ 48,756,000)$, and

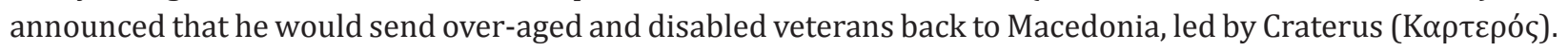

26 For more details, see Kallianiotis (2016b, Table 2b, 6).

27 Justin is the author of Historiarum Philippicarum libri XLIV.

28 See all these detailed calculations in Kallianiotis (2016b, table 2b, 7).

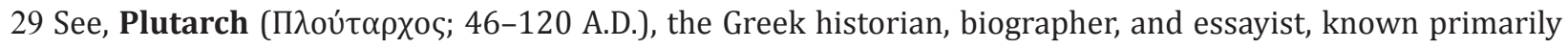

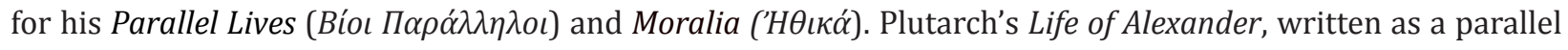
to that of Julius Caesar, is one of only five extant tertiary sources on the Macedonian conqueror Alexander the Great.

30 The total cost was $688,220,000$ Drs or $\$ 1,973,814,960(468,000,000$ Drs $+173,420,000$ Drs $+46,800,000$ Drs). See Table 2, 4 and Kallianiotis (2016b, Table 2b, 4).

31 The donation per soldier was: 18,000,000 Drs : 117,850 men $=152.74$ Drs/soldier.

32 The bonus per person was: 78,000,000 Drs : 117,850 men $=661.86$ Drs/soldier.

33 A total cost of 36,000,000 Drs (2,000 soldiers $\times 3$ talents $/$ man $=6,000$ talents).

34 A total cost of $52,335,000$ Drs or $7,999,603.623$ ozs or $\$ 150,096,780$. 
His troops misunderstood his intention and mutinied at the town of Opis $(\tilde{\Omega} \Omega \mathrm{t} \iota) .{ }^{35}$ They refused to be sent away and criticized his adoption of Persian customs and dress and the introduction of Persian officers and soldiers into Macedonian units. ${ }^{36}$ The Macedonians quickly begged forgiveness, which Alexander accepted, and held a great banquet ${ }^{37}$ for several thousand of his men at which he and they ate together. In an attempt to craft a lasting harmony between his Macedonian and Persian subjects, Alexander held a mass marriage ${ }^{38}$ of his senior officers to Persian and other noblewomen at Susa. Also, Hephaestion's death and funeral had a cost

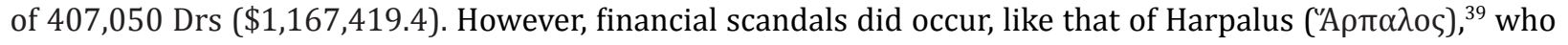
absconded large amounts of money of 4,200,000 Drs or $\$ 12,045,600$ (Table 2, 8). A summary of the total of all the expenses is presented at the end of Table 2 , which were $2,562,018,650 \operatorname{Drs}(\$ 7,347,869,488)$.

\section{Alexander's Empire: Budget Management, Revenue, and Tax System}

The revenues (poroe, тópol) needed for covering all these war expenses and managing a huge Empire were coming from different sources. At the beginning of the campaign ( $\dot{\varepsilon} \kappa \sigma \tau \alpha \tau \tau \varepsilon^{\prime} \alpha$ ) the money came mainly

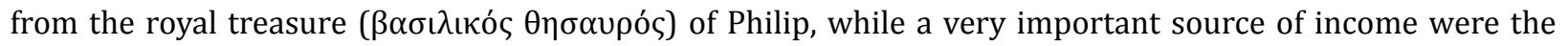
Macedonian mines ( $\mu \varepsilon \tau \alpha \lambda \lambda \varepsilon \tau \tilde{\alpha}),{ }^{40}$ producing gold and silver for the minting of coins (money). Incomes also

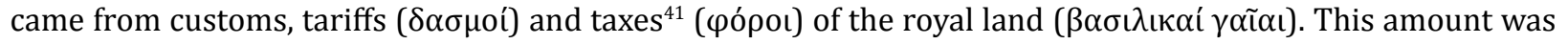
6,000 talents per annum or $36,000,000$ Drs or $\$ 103,248,000$ (Table 3,3 ). Another source of revenue was borrowing through loans. According to Plutarch, Alexander borrowed short-term 1,460 talents $(8,760,000$ Drs or 1,338,999.288 ozs). ${ }^{42}$ The costs for professional mercenaries ( $\mu \iota \theta 0 \varphi$ ó $\rho \omega \nu$ ) were covered exclusively from the royal treasure and the cost of the Macedonian army partly was covered from aristocracy grants ( $\chi 0 \rho \eta \gamma^{\prime} \alpha \iota$

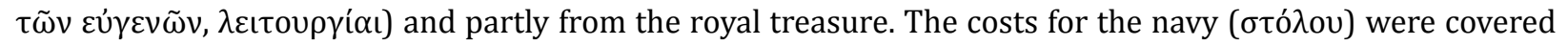

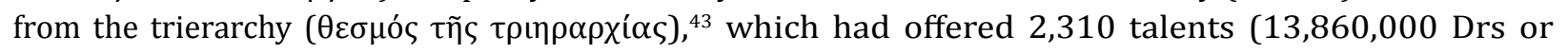
$\$ 39,750,480$ ). Some cities had undertaken to offer a number of triremes ( $\tau \rho \iota \eta ́ \rho \varepsilon เ \varsigma$ ) for the expedition and the expenses for their crew (Table 3,6).

Regarding the tax system of Alexander and its reforms, it seems to be very effective and fair; he did not impose

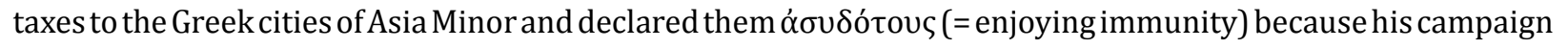
had as objective to liberate the Greek cities from a subjection tax ( $\varphi$ ó Darius. The non-Greek cities who did not resist the conqueror had to pay a certain amount of money (tax), in order to contribute to the "common cause", which was the punishment of Darius. But, taxes were imposed to foreign cities, who showed a hostile attitude towards Alexander, and the people of Ephesus ("Е $\varphi \varepsilon \sigma o \varsigma$, Ephesos),

35 Opis ( $(\Omega \pi \iota \varsigma)$ was an ancient Babylonian city near the Tigris, not far from modern Baghdad.

36 See, Worthington (2003).

37 With an estimated cost of 1,000,000 Drs or $\$ 2,868,000$. [Kallianiotis (2016b, Table 2b, 7)].

38 The cost of marriages is estimated to be 100,000 Drs or $\$ 286,800$; Kallianiotis (2016b, Table 2b, 7).

39 See, Kallianiotis (2016b, p. 22).

40 These mines exist even today; the Skouries mine on Halkidiki peninsula, North Greece. See, http://www. reuters.com/article/2014/01/13/us-greece-gold-insight-idUSBREA0C0DG20140113 . In addition, see, http:// www.mindat.org/loc-14183.html

41 See, Von Reden (2007).

42 In current dollars, this loan is $\$ 25,123,680$ (silver).

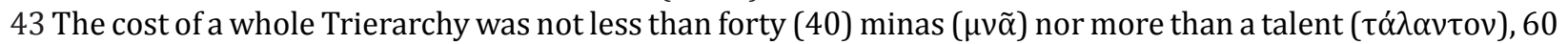
minas, with the average being 50 minas (50 minae x 100 Drs = 5,000 Drs). The responsibility of the Trierarchy as a liturgy was so great that during some eras no other liturgy could be assessed in the same or the following year. 
who put up a sturdy resistance to the conqueror. Justin (13.1.9) gives the annual tax revenue of Alexander as 30,000 Attic talents. Antigonos Monophthalmos ('Avtíyovos ò Movó $\varphi \theta \alpha \lambda \mu$ os; 382-301 B.C.) gives the amount to 11,000 talents. Herodotos (3.89) gives 9,000 Attic talents. ${ }^{44}$ We assume that total taxes were the moderate amount of 17,000 talents per annum (Table 3, 7). Also, other revenues came from plundering ( $\lambda \dot{\alpha} \varphi v \rho \alpha)$, during seizes of hostile cities.

Salt ( $\alpha \dot{\alpha} \lambda \varsigma$ ) was another necessary commodity, which was generating tax revenue for the Empire. It was a lot of trade of salt between the producers and the consumers. Plutarch is referring to the salt-ships, too. Even there were taxes on salt (salt-tax). Dardanians $\left(\Delta \alpha \rho \delta \alpha v^{\prime} \alpha\right.$, a region lying north of Macedonia) were imported salt from Macedonia. Also, spices (frankincense, cinnamon, myrrh, etc.) were trading all over the empire and were imported from India and other far Asian regions. Thousands of amphorae have been found and many other in ship wrecks, which show the size of trade and the commodities that were shipped from the place of production to the city of consumption (oil, wine, wheat, zea, ${ }^{45}$ etc.). Also, skins were used, as well, for the transportation of these commodities.

The annual revenue was not derived only from tribute and taxation, but also from the proceeds of the king's (Alexander's) own land and the natural resources that belonged to him, such as forests, mines and quarries, salt pans, etc. The term taxation denotes the total revenue of Alexander and his administration. As it was mentioned above, Justin (13.1.9) gives the annual income of Alexander as 30,000 Attic talents $(180,000,000$ Drs or $\$ 516,240,000)$. Antigonos Monophthalmos said that he had received 11,000 talents as part of the revenue of the empire, which ended up in his hands at the time, when he had established a certain measure of authority over all the Asian provinces (Diodoros 19.56.5). ${ }^{46}$ The 30,000 talents must be the total revenue of the king and his administration from all sources, including royal land and natural resources. In Pseudo-Aristotle (Oikonomika, Book II, 1.4) there is a very brief description of the sources of "satrapal" revenue, which include,

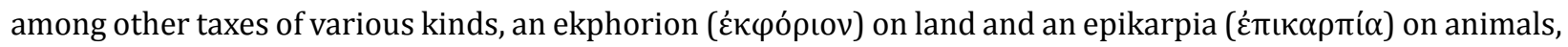

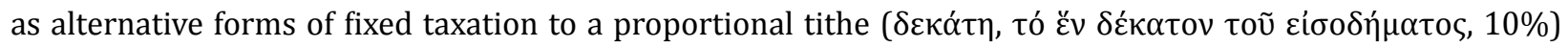
on both land and animals, though one cannot exclude the possibility that both taxes may have been applied simultaneously to the same individuals or corporate entities.

After capturing and liberating Asia Minor, Alexander journeyed south and was met by Darius' significantly larger army, but Darius was easily defeated, causing him to panic. Although he was chased by some troops, he did not captured, but Alexander took many prisoners of war and even Darius family. "Alexander treated them (Darius' family) with the respect out of consideration", which demonstrated his continued generosity and kindness towards those he conquered during his entire campaign. Darius fled the battle, causing his army to collapse, and left behind his wife, his two daughters, his mother Sisygambis, and a fabulous treasure. Darius offered a

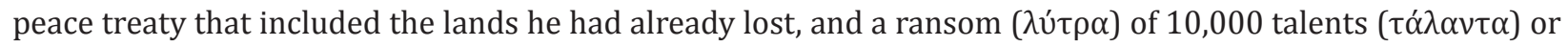
$60,000,000$ Drs or $9,171,228$ ozs $(\$ 172,080,000$ silver talents or $\$ 12,110,580,000$ gold talents) for his family (Table 3, 9). But, Alexander replied that since he was now king of Asia, it was he alone who decided territorial divisions. ${ }^{47}$ Alexander the Great realized that he had control and could receive much more. Darius was thus forced to come back. "This time the offer was impressive. Darius offered all territory as a far the Euphrates... a colossal ransom of 30,000 talents ${ }^{48}$ for his family...invited to marry his eldest daughter".

44 See, Aperghis (2001).

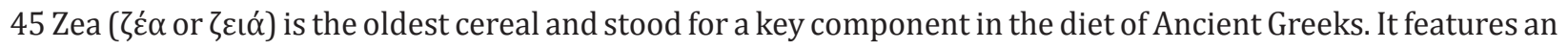

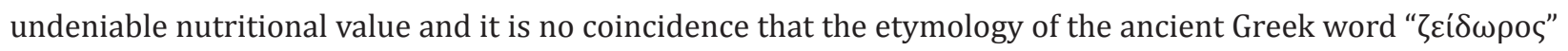
(zeidoros) meaning "life giving" comes from this particular cereal.

46 See, Aperghis (2001, p. 78).

47 See, Arrian (1976).

48 Which was $180,000,000$ Drs or $27,513,684$ ozs of silver $=\$ 516,240,000$ (today) or $\$ 36,331,740,000$ (if they

Volume 2016

Page 8 
Then, Alexander proceeded to take possession of Syria, and most of the coast of the Levant. In the following year, 332 B.C., he was forced to attack Tyre (Túpos), which he captured, after a long and difficult siege. ${ }^{49}$ When Alexander occupied Tyre, most of the towns on the route to Egypt quickly capitulated, with the exception of Gaza $(\Gamma \alpha ́ \zeta \alpha)$. The stronghold at Gaza was heavily fortified and built on a hill, requiring a siege. After three unsuccessful assaults, the stronghold fell. Jerusalem opened its gates in surrender, according to Josephus

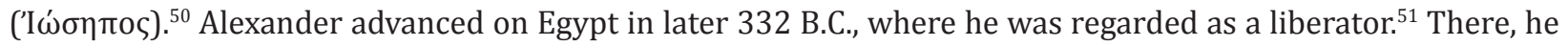
was pronounced the new "master of the Universe" and son of the deity of Amon ("A $\mu \omega \omega \nu$ ) at the Oracle ( $\mu \alpha v \tau \varepsilon \tilde{\tau}$ ) $)$ of Siwa Oasis in the Libyan Desert. ${ }^{52}$ Henceforth, Alexander often referred to Zeus-Ammon ("A $\mu \mu \omega v o \varsigma-\Delta$ ió ) as his true father, and subsequent currency depicted him adorned with ram's horn as a symbol of his divinity. ${ }^{53}$ During his stay in Egypt, he founded Alexandria-by-Egypt ('A $\lambda \varepsilon \xi \alpha$ ' $v \delta \rho \varepsilon เ \alpha$ ), which would become the prosperous

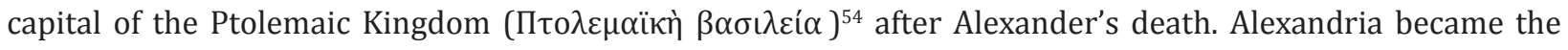
commercial, trade, intellectual, and cultural center of Southeast Mediterranean. ${ }^{55}$

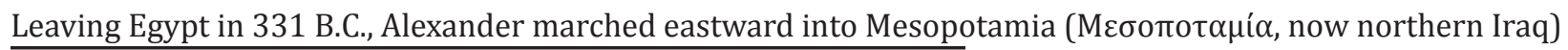
were gold talents). (Table 3, 9).

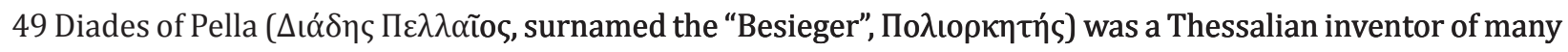
siege engines, student of Philip II's military engineer Polyidus of Thessaly. He lived in the 4th century B.C. Diades accompanied Alexander the Great in his campaigns to the East. He constructed (or improved) movable towers, battering rams, scaling engines used to scale walls and battering cranes used for the destruction of city walls. Diades was known as "the man who took Tyre with Alexander". He also wrote a treatise on machinery.

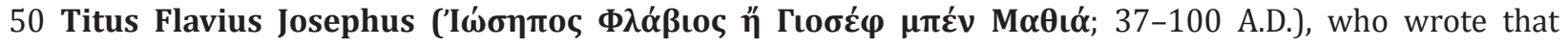
Alexander was shown the Book of Daniel's prophecy, presumably chapter 8, which described a mighty Greek king who would conquer the Persian Empire. He spared Jerusalem (another sign of this Holy City's future role that Alexander was a contributor) and pushed south into Egypt.

51 See, Ring, Salkin, Berney, and Schellinger (1994).

52 The tomb of Alexander the Great and, particularly, its exact present location has been a recurring conundrum. Shortly after Alexander's death (in the evening of June 11, 323 B.C. in the palace of Nebuchadnezzar

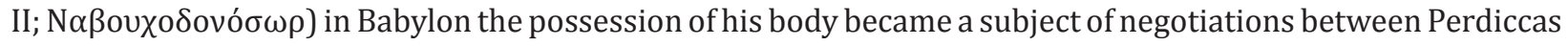

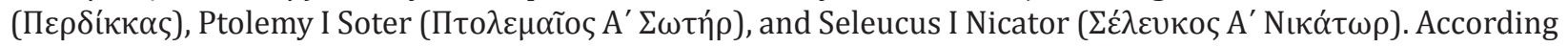
to Saunders (2007), while Babylon was the "obvious site" for Alexander's resting place, some favored to inter

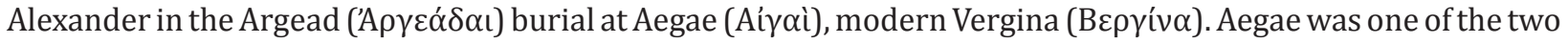
originally proposed resting places, according to Saunders, the other being Siwa Oasis and in 321 B.C. Perdiccas presumably chose Aegae. The body, however, was hijacked en route by Ptolemy I Soter. According to Pausanias

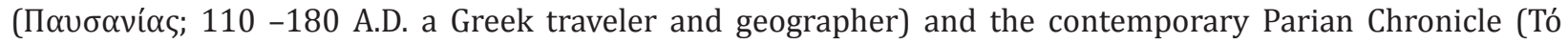

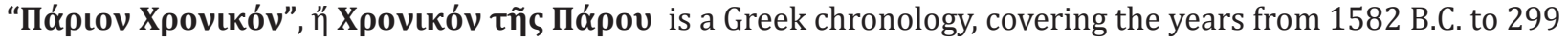

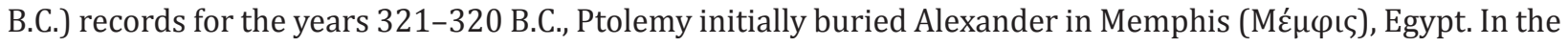

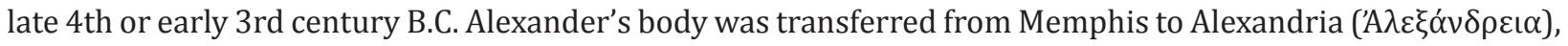
where it was reburied. See, Leana Souvaltzi, http://www.souvaltzi.gr/ekdoseis_eng.htm ; also, http://www. nytimes.com/1995/02/06/world/greek-team-doubts-site-holds-alexander-s-tomb.html and Souvaltzi (2002). Furthermore, Grimal (1992). Also, Saunders (2007).

53 See, Alexander's coins in Kallianiotis (2015b, Appendix).

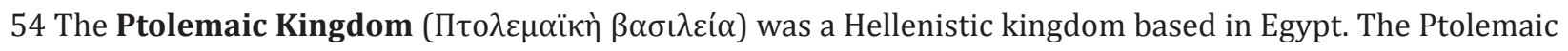
Kingdom was founded in 305 B.C. and it was ruled by the Ptolemaic dynasty, which started with Ptolemy I

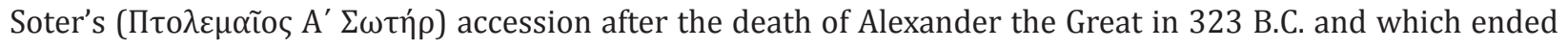

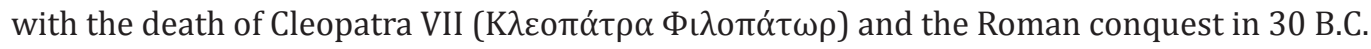

55 See, Kallianiotis (2016a). 


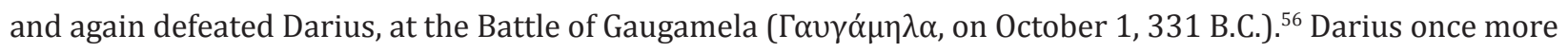
fled the field, and Alexander chased him as far as Arbela ("A $\mathrm{\beta} \beta \eta \lambda \alpha$ ). Gaugamela would be the final and decisive

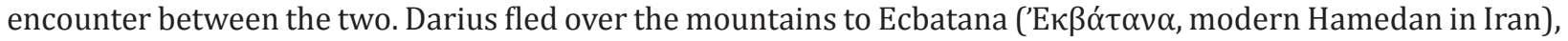
while Alexander captured Babylon (B $\alpha \beta \nu \lambda \omega ́ v)$. By the autumn of 330 B.C., Alexander was able to assemble at a central treasury at Ecbatana some 180,000-190,000 talents (Table 3, 11). ${ }^{57}$ By considering even the smaller amount of 180,000 talents $(1,080,000,000$ Drs or $\$ 3,097,440,000)$, it makes the second largest amount of treasure that Alexander had captured during his expedition.

Ancient sources tell that Alexander was facing financial difficulties until 333 B.C. But this is not correct because Alexander had 6,000 talents/annum from taxes on royal lands and over 11,000 talents/annum from other taxes, which made 17,000 talents/annum (102,000,000 Drs/annum or $\$ 292,536,000)$. Also, the loan of 8,760,000 Drs $(\$ 25,123,680)$ plus the contributions from the trierarchies. Later, and above all after the Battle of Gaugamela $(\Gamma \alpha v \gamma \alpha \dot{\alpha} \mu \eta \alpha)$ in 331 B.C., fabulous riches of the treasuries of Darius in Susa ( $\Sigma o \tilde{\sigma} \sigma \alpha)$ at the end of 331 B.C. and

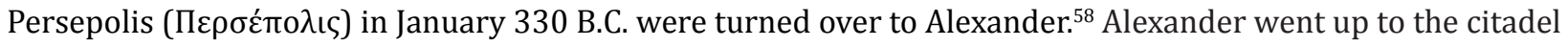
and took possession of the treasures stored there. They were full of gold and silver, with the accumulation

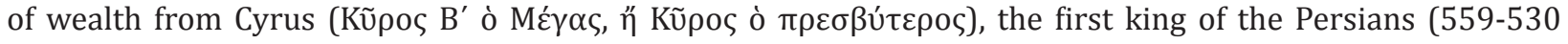
B.C.), down to that time. Reckoning gold in terms of silver, 2,500 tons were found there. (Table 3, 12). ${ }^{59}$ This was the largest amount of treasure that Alexander captured in Persia. From Babylon, Mesopotamia and Susa, he sent for a crowd of mules, partly pack and partly draught animals, as well as 3,000 dromedaries ( $\delta \rho 0 \mu \alpha \dot{s}$

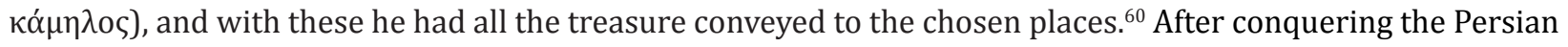
Empire, Alexander proceeded to tax and administration reforms, in order to control the vast empire and his management was very effective and fair for all people.

Alexander then chased Darius, first into Media, and then Parthia. The Persian king no longer controlled his

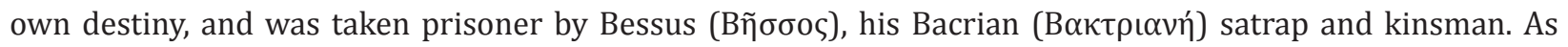
Alexander approached, Bessus had his men fatally stab the Great King and then declared himself Darius'

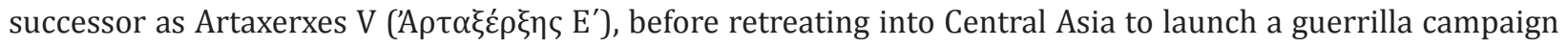
against Alexander. ${ }^{61}$ Alexander buried Darius' remains next to his Achaemenid predecessors in a regal funeral. He claimed that, while dying, Darius had named him as his successor to the Achaemenid throne. ${ }^{62}$ The Achaemenid Empire is normally considered to have fallen with Darius. But, Spitamenes ( $\Sigma \pi \imath \tau \alpha \mu \varepsilon ́ v \eta \varsigma)$, who held an undefined

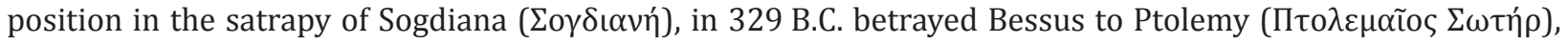
one of Alexander's trusted generals, and Bessus was executed. However, when, at some point later, Alexander 56 Arrian (1976).

57 See, Diodorus Siculus 17.80.3; Strabo 15.3.9; Justin 12.1.1. Also, Van De Mieroop (2014). This treasure was: $1,080,000,000-1,140,000,000$ Drs or $165,082,104-174,253,332$ ozs or $\$ 3,097,440,000-\$ 3,269,520,000$. (Table $3,11)$.

58 See, Diodorus Siculus 1963, 17.39.1. Also, Diodorus Siculus 1963, 17.48.2-17.49.2. Further, Arrian 1893, 3.1.

59 Which make up $96,153.84615$ gold talents or $576,923,076.9$ Drs or $88,184,903.84$ ozs of gold or $\$ 116,448,140,100$. (Table 3, 12). This gold/silver ratio is $1 / 10$; then, this treasure was $96,153.84615$ gold talents x $10=961,538.4615$ silver talents $\times 6,000$ Drs $=5,769,230,769$ Drs or $881,848,846.1$ ozs of silver or $\$ 16,543,484,350$.

60 ee, http://www.livius.org/aj-al/alexander/alexander_t12.html

61 See, Arrian (1976).

62 See, Gergel (2004). 


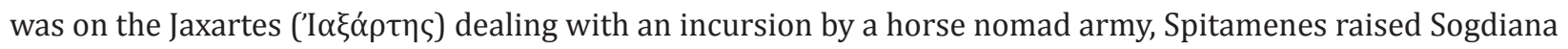

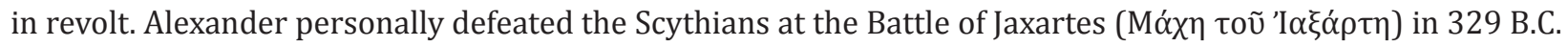
and immediately launched a campaign against Spitamenes, defeating him in the Battle of Gabai, in 328 B.C. After the defeat, Spitamenes was killed by his own wife, who then sued for peace.

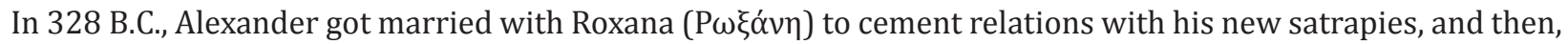
he turned to the Indian subcontinent. Omphis (" $\Omega \mu \varphi \iota s$, Indian name Ambhi Kumar), the ruler of Taxila (Tó $\xi ı \alpha$

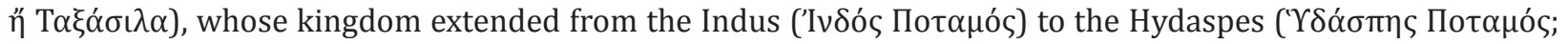

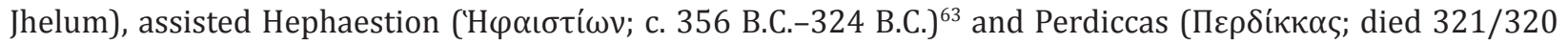
B.C.) in constructing a bridge over the Indus where it bends at Hund, supplied their troops with provisions, and received Alexander himself, and his whole army, in his capital city of Taxila, with every demonstration

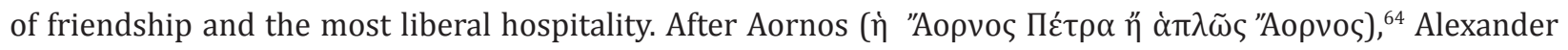

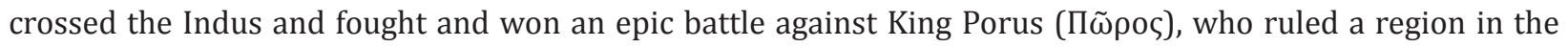

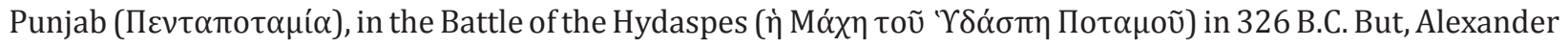
was impressed by Porus's bravery, and made him an ally. He appointed Porus as satrap, and added to Porus' territory land that he did not previously own. Alexander founded two cities on opposite sides of the Hydaspes

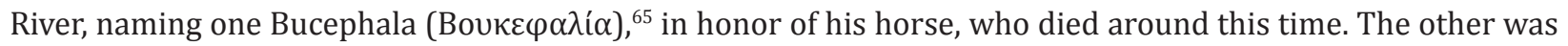

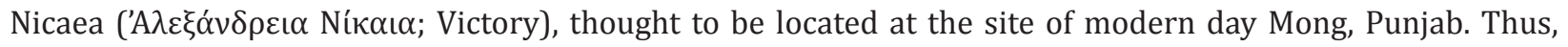

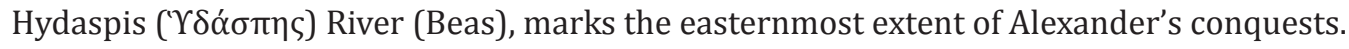

Now, Alexander tried to persuade his soldiers to march farther, but his general Coenus (Koĩvoc; died 326 B.C.) pleaded with him to change his opinion and return. "The men", he said, "longed to again see their parents, their

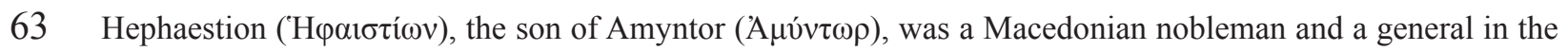
army of Alexander the Graet. He was "... by far the dearest of all the king's friends; he had been brought up with Alexander." This friendship lasted throughout their lives, and was compared, by others as well as themselves, to that

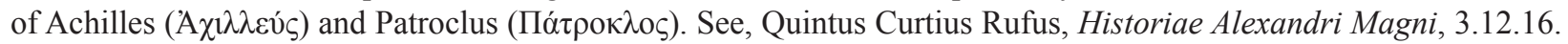
Ancient Greeks considered friendship as one of the highest values in a person's life. For this reason, we see to exalt

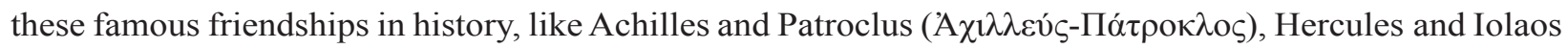

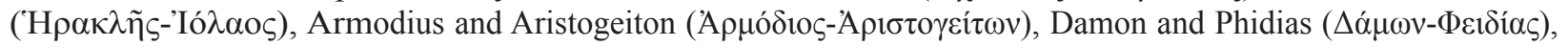

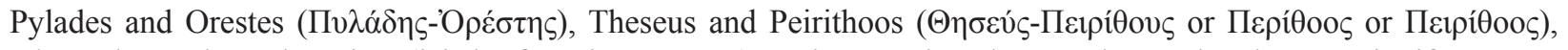
Alexander and Hephaestion ( $\left.\mathrm{A} \lambda \bar{\varepsilon}^{\prime} \xi \alpha v \delta \rho \varsigma_{-}-\mathrm{H} \varphi \alpha \iota \sigma \tau i \omega v\right)$. It is true that the Greeks rendered more significance to friendship in general than any other people. Thus, these pairs of friends were not without heirs in historical times. This

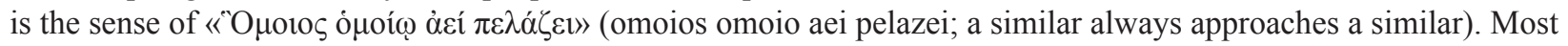
of these heroic friends have similar likes that stretch to sharing the same beliefs, the same problems and of course, the

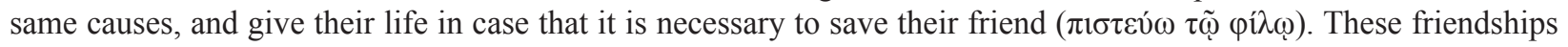
were moral and ethical relationships; there are no abnormal, shameful, and against human nature relationships between people of the same sex in Ancient Greece, as some ignorant and perverse pseudo-authors are writing. These lies have been spread to justify the current perversions of our declining immoral and unethical civilization. Of course, Christianity came in Greece in year 50 A.D. and these moral and ethical values of the past became even much stronger, due to the Revealed Truth, which classifies homosexuality as the deadliest sin for the human soul. Thus, homosexuality had and has no place in the Greek culture and value system. All the other views are myths from ignorant or suspicious for their behavior people. These groups of friends were representing the beauty, the bravery, and the moderation of the

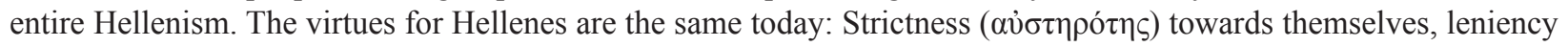

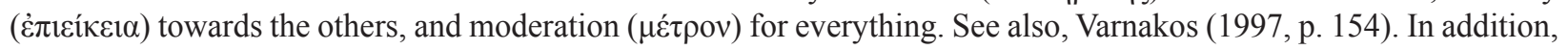
see, Kallianiotis (2013b). Also, 86.1\% of Greeks are against the marriage of homosexuals (e-grammes.gr). See also, Kallianiotis (2015a).

64 See, Lane Fox (1973). Also, Arrian, Anabasis IV, Chapters 28.1-30.4.

65 See, Lendering (2007). 
wives and children, their homeland". Alexander eventually agreed and turned south, marching along the Indus

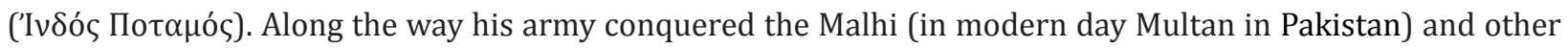
Indian tribes. Alexander sent much of his army to Carmania (modern southern Iran) with general Craterus

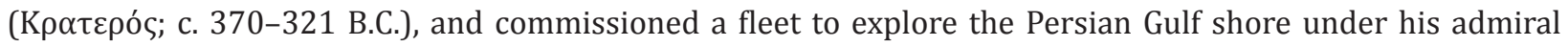

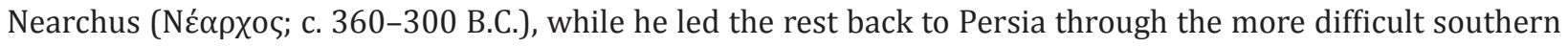
route along the Gedrosian Desert ( $\Gamma \varepsilon \delta \rho \omega \sigma i ́ \alpha$; an area that corresponds to today's Balochistan) and Makran (M $\alpha \kappa \rho \alpha v i ́ \alpha$; which is a semi-desert coastal strip in the south of Sindh and Balochistan, in Pakistan and Iran, along the coast of the Persian Gulf and the Gulf of Oman). Alexander reached Susa in 324 B.C., but not before losing many men to the harsh desert. ${ }^{66}$ After Alexander traveled to Ecbatana to retrieve the bulk of the Persian treasure,

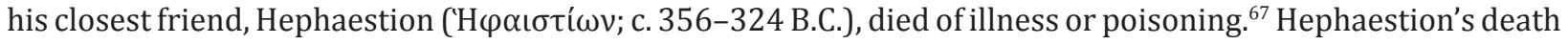
devastated Alexander, and he ordered the preparation of an expensive funeral ${ }^{68}$ in Babylon, as well as a decree for public mourning. Back in Babylon, Alexander planned a series of new campaigns, beginning with an invasion of Arabia, but he would not have a chance to realize them, as he died shortly thereafter.

On June 11, 323 B.C., Alexander died in the palace of Nebuchadnezzar II (N $\alpha \beta o u \chi o \delta o v o ́ \sigma \omega \rho$ B'), in Babylon, at age $33 .{ }^{69}$ Diodorus, Plutarch, Arrian and Justin all mentioned the theory that Alexander was poisoned. Justin stated that Alexander was the victim of a poisoning conspiracy, Plutarch dismissed it as a fabrication, ${ }^{70}$ while both Diodorus and Arrian noted that they mentioned it only for the sake of completeness. ${ }^{71}$ The accounts were

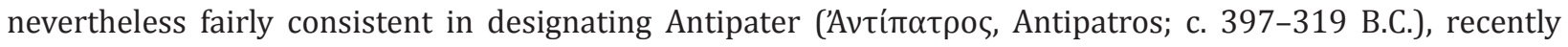

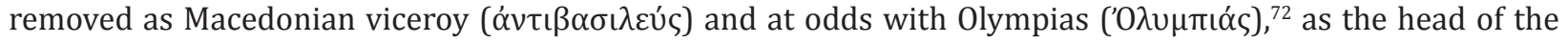
alleged plot.

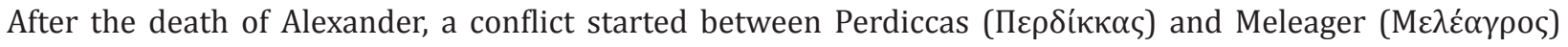
regarding the succession. Eventually, the two sides reconciled, and after the birth of Alexander IV ('A $\lambda \dot{\varepsilon} \xi \alpha v \delta \rho \circ \varsigma$

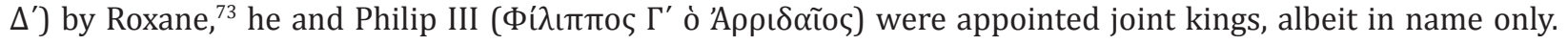
Dissension and rivalry soon afflicted the Macedonians, however. The satrapies handed out by Perdiccas at the Partition of Babylon became power bases each general used to bid for power. After the assassination of Perdiccas in 321 B.C., Macedonian unity collapsed, and 40 years of war between "The Successors" (Diadochi, $\Delta$ tó $\delta o \chi o r)$

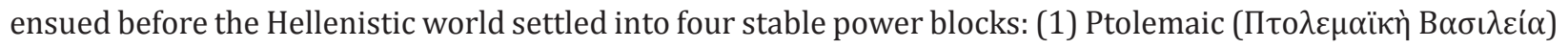

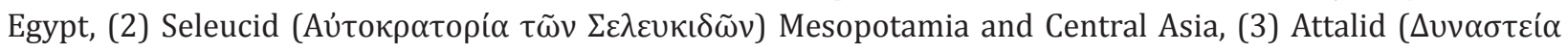

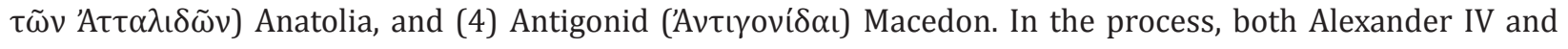
Philip III were murdered. ${ }^{74}$

66 See, Morkot (1996).

67 See, Arrian_(1976).

68 With an estimated cost of 407,050 Drs $(\$ 1,167,419.4)$. See, Kallianiotis (2016b, Table 2b, 7).

69 See, Depuydt, L. (1997), "The Time of Death of Alexander the Great: 11 June 323 BC, ca. 4:00-5:00 pm”. Die Welt des Orients 28: 117-35.

70 See, Plutarch (1919).

71 See, Siculus, Diodorus (1989). Arrian (1976).

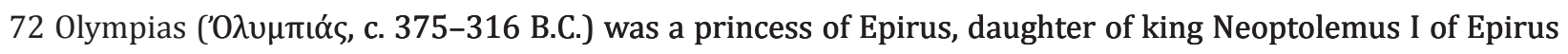

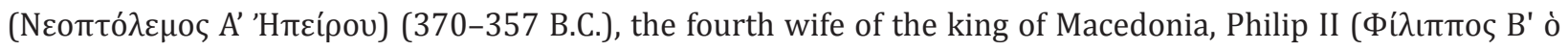

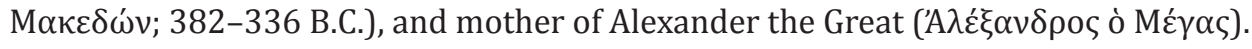

73 Alexander IV ('A $\lambda \dot{\varepsilon} \xi \alpha \nu \delta \rho \circ \Delta^{\prime}$; 323-311 B.C.), erroneously called sometimes in modern times Aegus, was the

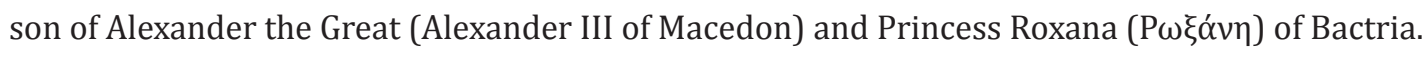

74 See, Green (2007). 


\section{Historic Lessons FRom the Hellenic Studies for Today's Economy ANd Society}

As it was seen above, these moral and ethical Greek (Hellen) Macedonians had greatly contributed to the civilization of the entire world of their times. Contemporary historians, Herodotus, Thucydides, Arrian, Polybius, Justin, Diodorus, Plutarch, and other sources write for these Greeks (Hellenes) and their King, Alexander the Great. These Macedonians by themselves were declaring since these ancient times that they were Greeks

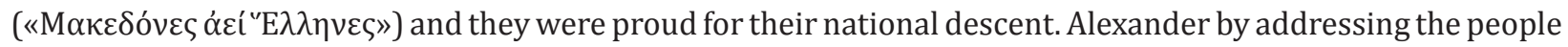
of Southern Greece was saying "my fellow Greeks". This Hellenism has given the foundations to all the Western nations and to Asian ones until the imposition of Islam on them after the $7^{\text {th }}$ century A.D. Today, all the wars are conquests and not civilizing ones, as it was Alexander's expedition; they cause enormous debts, casualties, execution of foreign leaders, war crimes, refugees, and destructions. Thus, Alexander's successful campaign and his economic management of a huge empire are very useful lessons for our leaders (unfortunately, followers).

For those, who know the Greek (Hellenic) language, which was also the language of all Greek city-states and regions, like the Ancient Macedonia; the names of Macedonians are all Greek and their culture, faith, and race, were Greek, too. The name Alexander ('A $\left.A \varepsilon^{\prime} \xi \alpha \nu \delta \rho o \varsigma\right)^{75}$ is Greek and it is composed by the two words, ALES $(\mathrm{A} \Lambda \mathrm{E} \Sigma)$ and ANDROS $(\mathrm{AN} \triangle \mathrm{PO} \Sigma)$. The first $(\mathrm{A} \Lambda \mathrm{E} \Sigma)$ renders the meaning of assembly of the same race overtime, ${ }^{76}$ i.e., Greeks ( $A=$ gathering, $\Lambda=$ similar-same race, $E=$ chronic, through time, $\Sigma$ =humans). Where the second (AN $\triangle \mathrm{PO}$ ) explains by whom all these people are brought together, namely by a man, who has indeed, high spirituality, strength, vision, energy, fighting power. ${ }^{77}$ Everything is Greek in Macedonians, from language to their entire civilization; and this Greek language ('E $\lambda \lambda \eta \nu \iota \kappa \alpha$ ) was used to translate the Old Testament and to write the Gospels (New Testament). ${ }^{78}$ The full name of Alexander the Great was Greek and it was, ${ }^{\prime} \lambda \varepsilon^{\prime} \xi \alpha \nu \delta \rho o \varsigma$

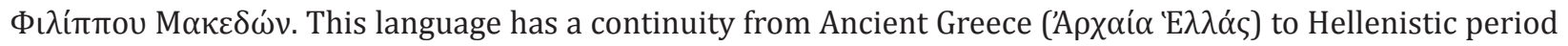

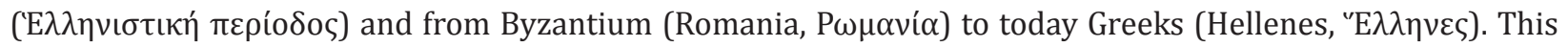
is God's Providence and we cannot change it, even though that there are many, who try with all their means to

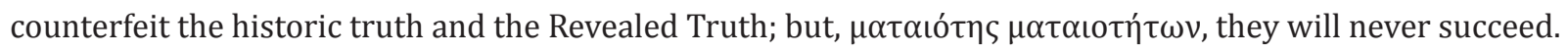

75 The letters of A- $\Lambda$-E- $\Xi-A-N-\Delta-P-O-\Sigma$ represent the numbers of the Greek alphabet, 1-30-5-60-1-50$4-100-70-200=521$ (their sum) $=8$, which symbolize a new beginning. The harmony in the Greek language is amazing. Ancient Greeks believed that all these words (the names of everything were the absolutely correct

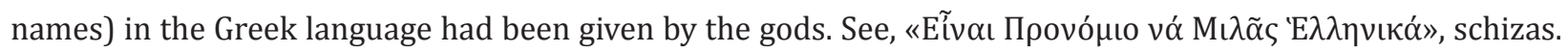
com, September 7, 2015, pp. 1-4.

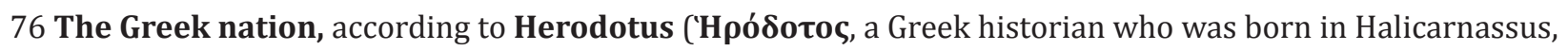

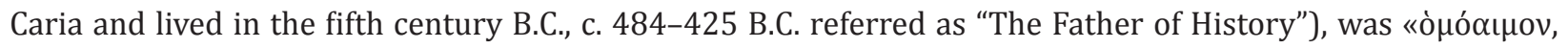

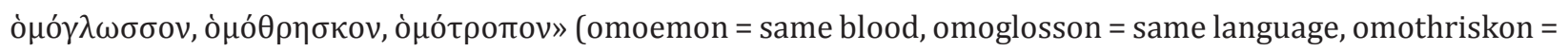
same religion, omotropon = same ways, behaviour); but, with any Greek City State maintaining its independent leadership and rulers, with their own alliances and their own civil wars in the Greek region. From Homer up to

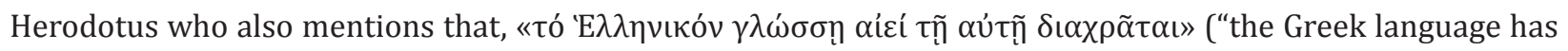
always been spoken"), but in the pass of time, in this long Greek history (7 thousands years), the Greeks were calling themselves with a variety of names. See, http://hellinon.net/EllinismosMakedonia.htm. Today, they try to destroy the sovereign nations by ruining their homogeneity (with the illegal immigrants) and by changing their traditional national languages and they are "very successful" (sic), due to our ignorance of history.

77 See, Varnakos (1997, pp. 49-50).

78 See, Kallianiotis (2016a). 
Alexander created the same economic conditions for his entire empire because he was their king, the same person, who exercised the same policy and his objective was to civilize all these areas and transfer to them the Hellenic civilization; then, after the conflicts came the symbiosis ( $\left.\sigma u \mu \beta^{\prime} \omega \sigma \iota \varsigma\right)$ of all these people within the same economic system. This ancient Greek system was developed, now, to the Alexander's socio-politico-economic system, then to Hellenistic one, to Roman later, and finally to the Byzantine new socio-spiritual system, which is actually the same ancient moral and ethical Greek system complemented by the revealed Truth. Even in the first half of the $20^{\text {th }}$ century the social life and economy in Greek villages was an expansion of these previous economico-social system and way of living, without any major effects from the industrial revolution of the West. The transformation in technology was very slow and the impact on the economy small and insignificant.

According to Plutarch, ${ }^{79}$ among Alexander's traits were a strong temper and rash, impulsive nature, which undoubtedly contributed to some of his decisions as a leader. Alexander was open to reasoned debate. He also had a calmer side (perceptive, logical, and calculating). He had a great desire for knowledge, a love for philosophy, and was an avid reader. These were no doubt in part, due to Aristotle's tutelage; Alexander was intelligent and quick to learn. His intelligent and rational side was amply demonstrated by his ability and

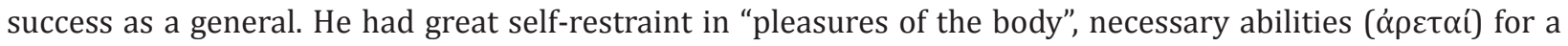
wise, brave, and true man. Alexander was erudite and patronized both arts and sciences. He was seeking the

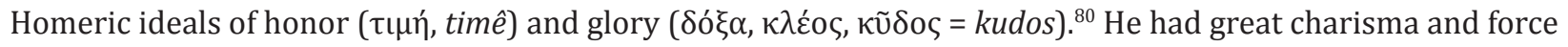
of personality, characteristics which made him the greatest of the leaders. His unique abilities were further demonstrated by the inability of any of his generals to unite Greece and retain the Empire after his death; only

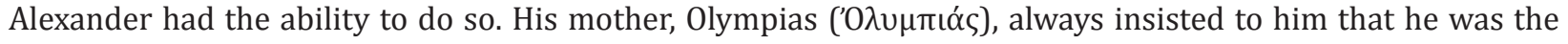
son of Zeus (Zeús), a theory apparently confirmed to him by the oracle of Amun at Siwa (an oasis in Egypt). ${ }^{81}$ Since that time, he began to identify himself as the son of Zeus-Ammon. Another oracle was found in pseudo-Callisthenes' biography of Alexander the Great. ${ }^{82}$

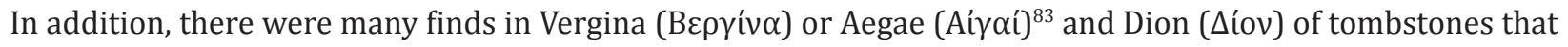
bear only Greek names. ${ }^{84}$ These tombstones provide strong evidence of the Hellenic origin of the Macedo-

79 Plutarch (1919) and Plutarch (1936).

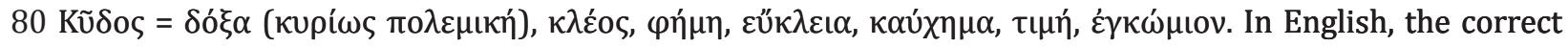
word must be "Kydos" (polemic glory) and not the wrong one, kudos that is used.

81 See, Liana Souvaltzi. http://www.independent.co.uk/news/world/some-talk-of-alexanders-tomb-starts-toring-hollow-1571876.html. Souvaltzi did the excavation at Siwa, Egypt, but some dark powers did not allow the continuation of her work to bring her findings to the light. http://www.nytimes.com/1995/02/06/world/ greek-team-doubts-site-holds-alexander-s-tomb.html See also, $\Sigma$ ouß $\alpha \lambda \tau \zeta \tilde{\eta}$ (2002).

82 See, Kallianiotis (2015b). Ancient Greek oracles were talking about the True God, too. See, http://friendshipiseverything.blogspot.com/2011/03/blog-post_9878.html and Kallianiotis (2016a).

83 Vergina = Aegae $\left(B \varepsilon \rho \gamma^{\prime} v \alpha=A i \gamma \alpha i ́\right)$ means water and coastal land, from which we have the name Aegean

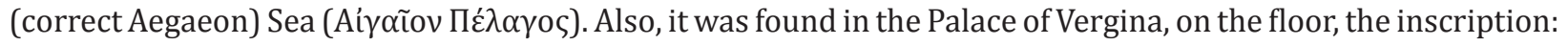

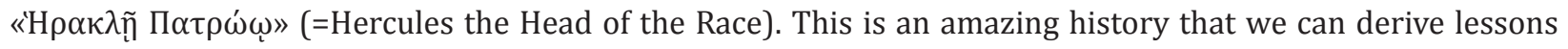
even today, but it is difficult for the current controlled leaders to do the appropriate connections.

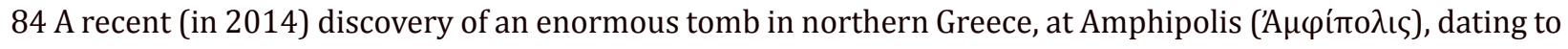
the time of Alexander the Great had given rise to speculation that its original intent was to be the burial place of Alexander. This would fit with the intended destination of Alexander's funeral cortege. But, something strange happened and they did not publicize the findings. Unfortunately, there are dark powers that they control even the historic truth. See, http://www.interalex.net/2014/12/amphipolis-greece-tomb-news-dec-10-2014.html . 
nians. ${ }^{85}$ Alexander's expedition was a Greek campaign to civilize the barbarian world of that period and to offer its language and paideia to Middle East, Asia, and Africa that all these people to be ready to accept the Revealed Truth, which was coming three centuries later. This civilization has contributed greatly to our socio-economico-political system from these distant times up to now. It is very difficult for us to decode and present more information on Alexander's economics; but, his contribution to the world is beyond the narrow economics, as this poor research tries to present.

Thus, Alexander's legacy to Hellenism and to humanity extended beyond his military conquests. His campaigns greatly increased contacts and trade between East and West, and vast areas to the east were significantly exposed to Greek civilization and influence. Some of the cities he founded became major cultural centers, many surviving into the 21st century. ${ }^{86}$ Actually, he prepared the ground for the "Unknown God" ${ }^{87}$ to become known to humanity through Alexander's Hellenistic language and civilization. ${ }^{88}$ Undoubtedly, Alexander's most immediate legacy was the introduction of Macedonian (Hellenic) rule to the huge new boundless extensions into Asia. Many of these remote areas remained in Greek (Hellenic) hands or under Greek influence for the next 300 years. The successor states that emerged were dominant forces, and these 300 years are often referred to

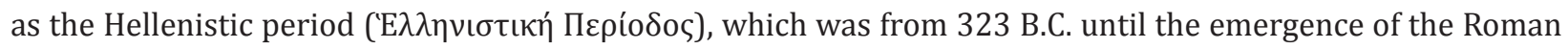
Empire as signified by the Battle of Actium in 31 B.C. He managed his wars and his empire by exercising an efficient and effective public policy with a revenue for these 13 years of 8,413,850,769 Drs $(1,286,089,063$ ozs or $\$ 24,130,924,010)$ and expenditures of $2,562,018,650$ Drs $(391,614,286.3$ ozs or $\$ 7,347,869,488)$, which generated a surplus at the end of 5,851,832,119 Drs or $894,474,776.7$ ozs or $\$ 16,783,054,522$ (Tables 2 and $3)^{89}$ Also, he was generous in his payments. He was paying his soldiers from $1 \mathrm{Dr} /$ day $=0.1528538$ ozs $/$ day or $\$ 7.612 /$ day to $6.66 \mathrm{Drs} /$ day $=1.0180063 \mathrm{ozs} /$ day or $\$ 50.697 /$ day. ${ }^{90}$

Over the course of his conquests, for thirteen years (336-323 B.C.), Alexander founded some twenty cities that

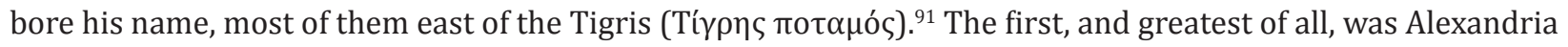

Also, http://greece.greekreporter.com/2014/12/04/lingering-mysteries-of-the-amphipolis-tomb/ . Further, http://en.protothema.gr/pres-pavlopoulos-only-fools-may-doubt-that-macedonia-is-greek/

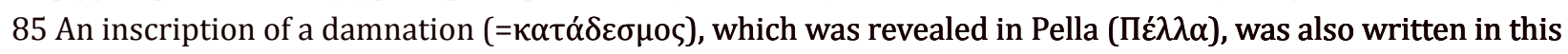
superior Greek language. See, I. N. Kallianiotis, "An Archaeological Perspective of the Macedonian Question",

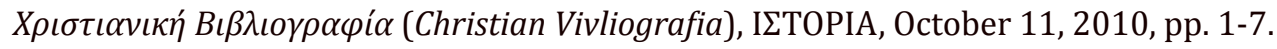

http://christianvivliografia.wordpress.com/2010/10/11/an-archaeological-perspective-of-themacedonian-question/

86 We see ISIS, today, destroying the Hellenic exhibits in museums in Iraq and other areas in the Middle East. See, http://www.theguardian.com/world/2015/feb/26/isis-fighters-destroy-ancient-artefacts-mosul-museum-iraq. Also, they blew up the Hellenistic city of Palmyra (Syria) in August 2015 and the West was watching happily that globalization will be established without any obstacle, after terrorizing Europeans. (sic). See, The New York Times, August 24, 2015. http://www.nytimes.com/2015/08/24/world/middleeast/islamic-stateblows-up-ancient-temple-at-syrias-palmyra-ruins.html?_r=0. See also, The New York Times, April 5, 2016.

http://www.nytimes.com/2016/04/05/world/middleeast/palmyra-syria-isis.html?_r=0

87 See, Apollo's prophesies. http://www.apologitis.com/gr/ancient/profiteies.htm\#E $\Lambda \Lambda H N E \Sigma$

88 See, https://www.youtube.com/watch?v=4mXeMU4c140

89 This gives an average annual surplus of $450,140,932.2$ Drs or $\$ 1,291,004,194$ [ $(=\$ 24,130,924,010$ $\$ 7,347,869,488): 13]$.

90 See, Kallianiotis (2015b and 2016b).

91 See, Arrian 1976, IV, 5-6, 16-17. For this reason, many historians, today, say that "Greece is extended east

Volume 2016

Page 15 
('A $\lambda \varepsilon \xi^{\prime} \alpha \dot{\alpha} \nu \rho \varepsilon\llcorner\alpha)$ in Egypt, which would become one of the leading Mediterranean cities until the $7^{\text {th }}$ century A.D., when Muslims took over the area. ${ }^{92}$ These cities' locations reflected trade routes as well as defensive positions. A century or so after Alexander's death, many of the Alexandrias were thriving, with elaborate public buildings, libraries, and substantial populations that included both $\mathrm{Greek}^{93}$ and local peoples. The population of Alexander's Empire was around 30-35 million ${ }^{94}$ and his tax revenue 30,000 talents $(180,000,000$ Drs); thus, $180,000,000$ Drs : $30,000,000$ people $=6$ Drs/person or $\$ 17.208$. The annual salary was 360 Drs and the tax 6 Drs (tax rate less than 1.7\%). Rostovtzeff (1953) said that in the $4^{\text {th }}$ century in Athens was a massive increase in the circulation of coinage, which led to a rise in prices of food stuffs and other commodities. Thus, Athens lost the markets, due to high prices and this caused the gradual decline in Greece. We also saw inflation during Alexander's possession of the Persian treasure.

Further, the economic growth is obvious after this unification of the vast empire and its excellent public finances. The wealth accumulation was spent by the Hellenistic kings, as well as with the large size of the military and the scale of the welfare expenditures from Alexander the Great and with his successors. The new towns, their increasing sizes, the new settlements, the cultivations of new land, trade, and shipping had improved the living standards among Greek and foreign citizens and the elites in the homeland and in Asia for many years. ${ }^{95}$

Banks ( $\tau \rho \alpha \dot{\pi} \tau \zeta \zeta \alpha$, trapezai) had been developed in Athens since fifth century B.C. and were expended in the entire empire. Their transactions had increased the issues of coinage and other alternative payments system; the forward market was used extensively in the agricultural economy. A merchant was buying in advance a crop, which would be ready for harvest a few months later, at a predetermined (contractual price), the forward price. Cohen (1992) argues about a high development of banking, credit, and legislation about interest rates. These institutions and the economic conditions were used and improved by Alexander and his successors.

Royal banks ( $\beta \alpha \sigma \iota \lambda \iota \kappa \alpha i ́ ~ \tau \rho \alpha ́$ $\pi \varepsilon \zeta \alpha \iota$, basilikai trapezai) were established as treasuries, for tax-collection purposes and foe currency exchange. Coinage created a focus on the monarchy of Alexander the Great and brought a greater cohesion in a regionally diverse empire. Displays of money, bonuses, social institutions, and conspicuous expenditures by Alexander on the occasion of victories and festivals associated money with power, prosperity, and growth, while donations and public rewards made money part of an incentive for people to work and a structural reform of the Alexander's public policy (expansionary fiscal policy). The production of Alexander's coinage, after acquiring the Persian treasures, seems to have been tremendous (about 1,200,000 talents; Table

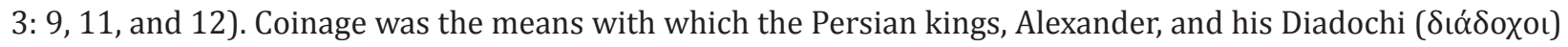
displayed their wealth and which they used for the expenditures of their wars and for the public works (investments) of the empire.

until Babylon".

92 Greeks are in Alexandria, Egypt, since those days up to now. The Greek community, there, with the Patriarchate of Alexandria and the Greek Patriarch are thriving and contribute to the life of the city and the entire Africa even, today.

93 Also, these Greeks in the Palestine region went to meet Jesus, as we see in the Bible: "Now there were certain Greeks among those who came up to worship at the feast. Then they came to Philip, who was from Bethsaida of Galilee, and asked him, saying, 'Sir, we wish to see Jesus'. Philip came and told Andrew, and in turn Andrew and Philip told Jesus. Jesus answered them, saying, 'The hour has come that the Son of Man should be glorified' [by

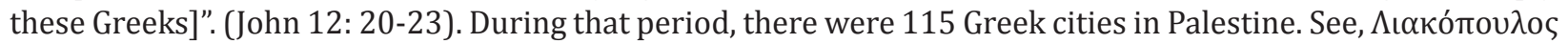
(2000).

94 See, Aperghis (2001, p. 79).

95 See, Von Reden (2007). 
Monetary taxation and royal rents provided part of this revenue (from 9,000 to 30,000 talents the first and 6,000 talents the second per annum; Table 3: 3 and 7). Coinage increased the efficiency of the administration and generated a royal surplus. The trade and the export of agricultural products (grain, oil, wine, etc.) provided the basis for the influx of precious metal coinage from the other parts of the empire and later from the other Kingdoms of the Hellenistic world.

Ultimately, Alexander was the only true civilizer in human history, a great leader, an excellent general, and a very

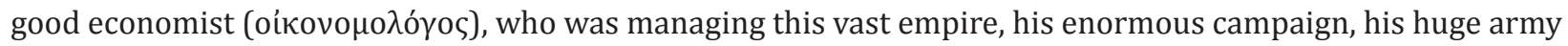
and personnel, and their expenses; but also he was administrating the different sources of revenue not only to balance the empire's budget, but he had surpluses, too. Greece enjoyed a period of peace and prosperity during Alexander's campaign in Asia. ${ }^{96}$ Alexander sent back to Greece vast sums of money from his surpluses and other valuables from his conquest; his wages and all his compensations were very generous, which stimulated the economy and increased trade across his empire. ${ }^{97}$ But, even the contribution of his successors ( $\Delta$ เó $\delta$ oxol) was enormous for the next three hundred years. ${ }^{98}$

\section{CONCLUDing REMARKS}

Hellenism's contribution to the world is known to everyone, but one of its greatest offers was with its offspring Alexander (MÉ $\gamma \alpha \varsigma^{\prime} A \lambda \dot{\xi} \xi \alpha \nu \delta \rho \varsigma_{\text {) }}$. Alexander III Macedon (July 20, 356-June 11, 323 B.C.) earned the epithet, "the Great", due to his unparalleled success as a king, a military commander, and a civilizer of the known world at that time. ${ }^{99}$ He never lost a battle, despite typically being outnumbered. This was due to use of terrain, phalanx $(\varphi \alpha ́ \lambda \alpha \gamma \xi)$ and cavalry tactics, bold strategy, and the fierce loyalty of his troops. He always was personally

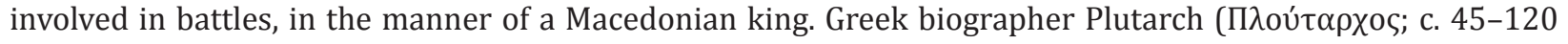

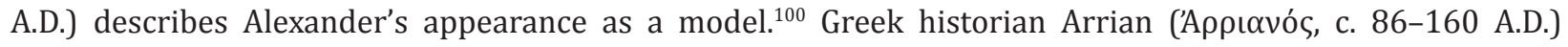
described Alexander as: "[T]he strong, handsome commander with one eye dark as the night and one blue as the sky" ${ }^{101}$ Ancient authors recorded that Alexander was so pleased with portraits of himself created by

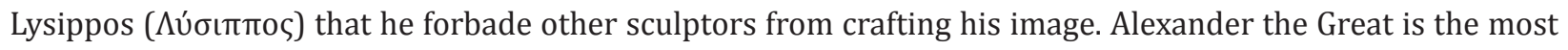
admired leader in human history. ${ }^{102}$

Of course, some of Alexander's strongest personality traits formed in response to his parents. ${ }^{103}$ His mother had huge ambitions, and encouraged him to believe it was his destiny to conquer the Persian Empire. ${ }^{104}$ Olympias' influence instilled a sense of destiny in him; of course, without preventing God's Providence. However, his father Philip II (382-336 B.C.) was Alexander's most immediate and influential role model, as the young Alexander

96 See, Roisman and Worthington (2010).

97 Today, the Troika reduces wages, salaries, and pensions and increases the tax rates in Euro-zone (particularly in Greece) to cut down the budget deficits, as it asserts, and has destroyed growth and consequently, it has decreased the tax revenue, which have augmented the budget deficits. What a public policy that these institutions impose on the countries and their controlled leaders (followers) do not say NO! They ignore history and Alexander's public policies. Thus, they cannot claim that they are GREEKS.

98 See, Kallianiotis (2016a).

99 Roisman and Worthington (2010).

100 See, Plutarch (1919).

101 See, "Alexander the Great". Mithec.

102 This is the reason that many non-Greek people, even foreign nations (like, the Slavic Skopje), claim that they are Macedonians, descendants of Alexander the Great. (sic). But, this is not true.

103 See, Green (2007).

104 Greeks are saying, even today, that "behind a saint, there is always a holy mother". 
watched him campaign practically every year, winning victory after victory while ignoring severe wounds. ${ }^{105}$ Alexander's relationship with his father forged the competitive side of his personality; he had a need to out-do his father, ${ }^{106}$ illustrated by his reckless behavior in battle. Alexander married twice. First, Roxana (P $\left.\omega \xi \alpha \dot{\alpha} \eta\right)$,

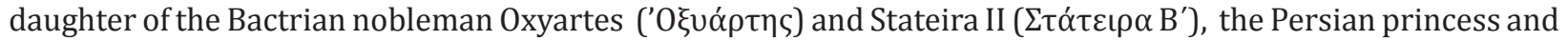

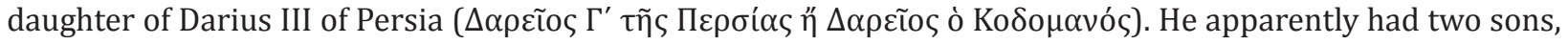

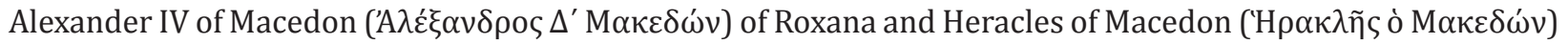
from his mistress Barsine (B $\alpha \rho \sigma i ́ v \eta)$. Apart from wives, Alexander had many more female companions. ${ }^{107}$ Nevertheless, Plutarch described how Alexander was infatuated by the pretty Roxana.

In addition, Alexander's economic abilities were also excellent. He managed the economy of his wars; an enormous campaign from Greece to India with success and very efficiently and also, the economic policy of his huge empire. His public policies [revenue, ( $\pi$ ó effective not only balancing his budget, but generated a surplus ( $\pi \lambda \varepsilon$ cóv $\alpha \sigma \mu \alpha)$, a portion of which was sent

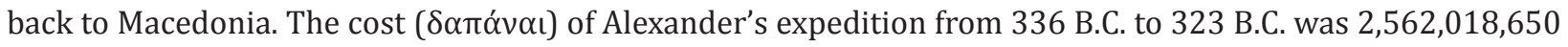
Drs, which was $391,614,286.3$ ozs of silver $(\$ 7,347,869,488$ in today's silver price). The revenue ( $\pi$ ópol) from different sources was $8,413,850,769$ Drs, which was $1,286,089,063$ ozs of silver $(\$ 24,130,924,010)$. Then, his surplus was $8,413,850,769-2,562,018,650$ Drs $=5,851,832,119$ Drs or $894,474,776.4$ ozs or $\$ 16,783,054,522$. (Tables 2 and 3). From the economic point of view, this is a good lesson for our politicians, today, who have generated an unsustainable national debt that they rollover to the next generations and the countries are facing bankruptcies. Our current social policies are very insignificant and the workers are extremely exploited by businesses and the unregulated markets that make enormous profits, create inflation, redistribute the wealth without generating new one, and avoid paying taxes, too. Then, we need to learn from the past history.

Further, with the word Hellenization we denote the spread of Greek language, culture, and population into the former Persian Empire after Alexander's conquest. That this export of Greek civilization took place is undoubted, and can be seen in the great Hellenistic cities of, for instance, Alexandria, Antioch, and Seleucia (south of Baghdad). Thus, Hellenization occurred throughout this vast region. The core of this Hellenistic culture was essentially Athenian (from the "golden age" of the city); the moral and ethical teaching of its philosophers. The close association of men from across Greece in Alexander's army directly led to the emergence of the largely

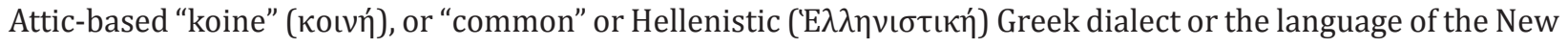

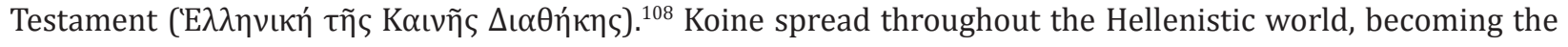

105 See, Roisman and Worthington (2010).

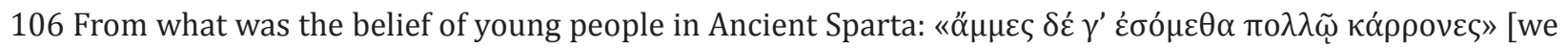
shall become better (than you)].

107 As we see, Alexander had been married twice and had many other women companions, which shows his relationships with women. Of course, no ancient sources stated that Alexander had homosexual relationships

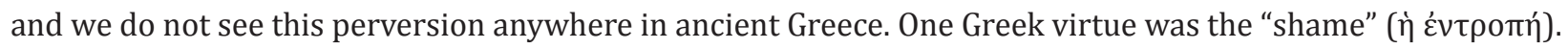
This was a big lie by some contemporary homosexuals to justify their anomaly (their deadly sin). The vice of homosexuality existed in Sodom and Gomorrah and God burnt them with fire and brimstone.

108 Koine Greek displayed a wide spectrum of different styles, ranging from more conservative literary forms to the spoken vernaculars of the time. As the dominant language of the Byzantine Empire (Romania, P $\omega \mu \alpha v i ́ \alpha$, $\mathrm{P} \omega \mu$ по 'í), it developed further into Medieval Greek, the main ancestor of Modern Greek. Literary Koine was the medium of much of post-classical Greek literary and scholarly writing, such as the works of Plutarch and Polybius. Koine is also the language of the Christian New Testament, of the Septuagint (the 3rd-century B.C. Greek translation of the Hebrew Bible, "Old Testament"), and of most early Christian theological writing by the Church Fathers. (St. Basil the Great and St. Gregory the Theologian studied in Athens in the $4^{\text {th }}$ century A.D.). 
lingua franca ${ }^{109}$ of Hellenistic lands and eventually the ancestor of Modern Greek. Furthermore, town planning, education, local government, and art current in the Hellenistic period were all based on Classical Greek ideals, evolving into distinct new forms commonly grouped as Hellenistic. Aspects of Hellenistic culture were evident in the traditions of the Byzantine (Medieval Greek) Empire up in the mid-15th century and they are still present even in today's Greece. The entire of long duration Greek culture is based on tradition, which is preserved and is transferred from one generation to the other. This tradition cannot be interrupted because the losses will be infinite not only for Greece, but for the entire world.

Lastly, Alexander the Great was a gifted man by God (of course, God's Providence is in control of His entire creation). His role in history is unique and he had all these talents to pursue this historic objective, the preparation of the known world to accept the Revealed Truth, the Messiah, the Son of God, "the Unknown God" of Socrates and of the other Greek philosophers. ${ }^{110}$ Actually, Alexander was the Greek "social forerunner" of the Lord. The divine plan was successful in only twelve (12) years (335-323 B.C.) and was preserved with Alexander's successors. Alexander's short life for only 33 years (356-323 B.C.) was enough to accomplish God's plan for humans' salvation. ${ }^{111}$ He was successful in all his tasks and of course, in his economic policy and triumphant in his social, foreign, and global policies. The problem, today, is that our leaders (even the religious leaders) do not receive God's Grace and do not accept God's Providence because they do not believe in the True God and their people (the poor citizens) are paying an enormous social cost.

Table 1. Attic or Athenian Talent (pure silver)

\begin{tabular}{|c|c|c|c|c|c|c|c|c|c|}
\hline \multicolumn{10}{|c|}{$\begin{array}{l}1 \text { gold talent }=26 \mathrm{Kgs}=57 \mathrm{lbs}=917.123 \mathrm{ozs}=6,000 \mathrm{Drs}=300 \text { gold staters }=60 \text { mnae }=36,000 \text { oboloi }=\$ 1,211,060.922 \\
1 \text { silver talent }=26 \mathrm{Kgs}=57 \mathrm{lbs}=917.123 \mathrm{ozs}=6,000 \mathrm{Drs}=3,000 \text { silver staters }=60 \text { mnae }=36,000 \text { oboloi }=\$ 17,205.227\end{array}$} \\
\hline \multicolumn{8}{|c|}{ Currency Parities } & \multirow[t]{2}{*}{ Gold } & \multirow{2}{*}{$\begin{array}{l}\text { Silver } \\
\text { lars }\end{array}$} \\
\hline Talents & Kgs & lbs (pounds) & Ounces & Drs & mnae & staters & oboloi & & \\
\hline 1 talent & 26 & 57 & 917.123 & 6,000 & 60 & 3,000 & 36,000 & $\$ 1,211,060.922$ & $\$ 17,205.227$ \\
\hline 0.03846 & $1 \mathrm{Kg}$ & 2.19231 & 35.27396 & 230.76923 & 2.3076923 & 115.3846 & $1,384.615$ & $\$ 46,579.264$ & $\$ 661.739$ \\
\hline 0.01754 & 0.45614 & $1 \mathrm{lb}$ (pound) & 16.08988 & 105.26316 & 1.052631579 & 52.63158 & 631.5789 & $\$ 21,246.687$ & $\$ 301.846$ \\
\hline 0.00109037 & 0.02834952 & 0.062150878 & $1 \mathrm{oz}$ & 6.54219772 & 0.065421977 & 3.271099 & 39.2532 & $\$ 1,320.50$ & $\$ 18.76$ \\
\hline 0.00016667 & 0.00433333 & 0.0095 & 0.1528538 & $1 \mathrm{Dr}$ & 0.01 & 0.5 & 6 & $\$ 201.843$ & $\$ 2.868$ \\
\hline 0.016666667 & 0.43333333 & 0.95 & 15.285383 & 100 & 1 mna & 50 & 600 & $\$ 20,184.348$ & $\$ 286.754$ \\
\hline 0.00033333 & 0.0086666 & 0.019 & 0.3057076 & 2 & 0.02 & 1 stater & 12 & $\$ 471.519$ & $\$ 5.735$ \\
\hline 0.00002777 & 0.0072222 & 0.0015833 & 0.0254756 & 0.1666666 & 0.00166666 & 0.08333333 & 1 obol & $\$ 33.641$ & $\$ 0.478$ \\
\hline 0.00000083 & 0.00002147 & 0.00004707 & 0.0007573 & 0.0049543 & 0.000049543 & 0.00247717 & 0.0297261 & & $\$ 1$ \\
\hline
\end{tabular}

Note: Talents $(\tau \alpha \dot{\alpha} \lambda \alpha \nu \tau \alpha)$ and mnae ( $\mu \nu \alpha \hat{)})$ were never minted; they represented weight measures; 1 talent = In this context, Koine Greek is also known as "Biblical", "New Testament", "Ecclesiastical” or "Patristic" Greek (and as a good American friend is saying, "this is the language that is spoken in Paradise"). It also continues to be used as the liturgical language of services in the Greek Orthodox Church. This holy language is under persecution the last forty years by the enemies of the Hellenic-Orthodox paideia, as it is anything valuable in human civilization.

109 A lingua franca (plural: lingue franche or lingua francas), also known as a bridge language, trade language or vehicular language, is a language systematically (as opposed to occasionally, or casually) used to make communication possible between persons not sharing a native language, in particular when it is a third language, distinct from both native languages, as it is the English language, today.

110 See, http://www.sakketosaggelos.gr/Article/172/ . Also, Kallianiotis (2016a).

111 Also, 33 years was the earthy life of the Son of God, Jesus Christ. 
$26 \mathrm{kgs}=917.123 \mathrm{ozs}$ and $1 \mathrm{mna}=0.43333 \mathrm{kgs}=15.28538$ ozs. Price of gold is with June $30,2016(\$ 1,320.50 /$ oz) and Price of silver is with June 30, 2016 (\$18.76/oz). The last row of the Table shows the insignificant value of the dollar (\$1) with respect the ancient currencies (the dollar is completely undervalued). 'H $\lambda \varepsilon^{\prime} \xi \mathrm{L}$

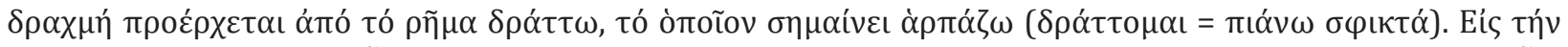

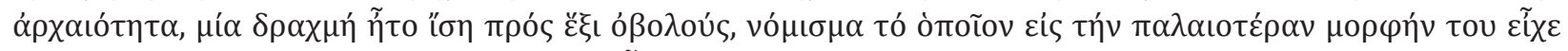

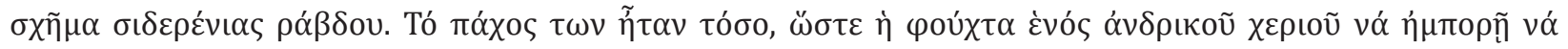

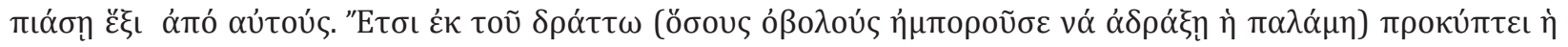

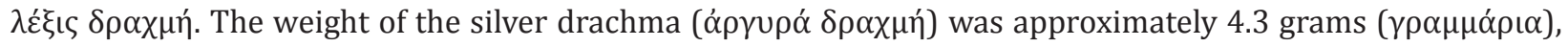
although weights varied significantly from one city-state to another. It was divided into six obols (óßo 0.72 grams, which were subdivided into four tetartemoria ( $\tau \varepsilon \tau \alpha \rho \tau \eta \mu o ́ \rho \iota \alpha)$ of 0.18 grams, one of the smallest coins ever struck, approximately $5-7 \mathrm{~mm}$ in diameter. Minae ( $\mu \nu \alpha i ́)$ and talents ( $\tau \alpha \dot{\lambda} \lambda \alpha \nu \tau \alpha$ ) were never actually minted: they represented weight measures used for commodities (e.g. grain) as well as metals like silver or gold, which help us, today, to make a comparison of these measures with ours. The New Testament mentions

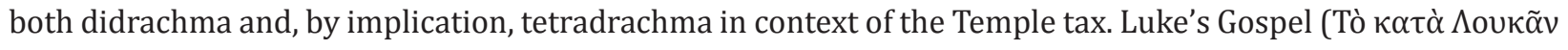

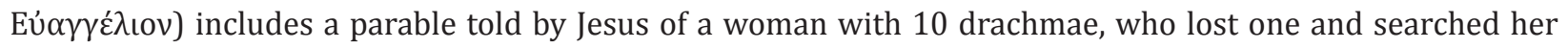
home until she found it. (Luke 15:8-10).

Source: British Museum Catalogue 11 - Attica Megaris Aegina; American Numismatic Society (1916). American Journal of Numismatics. 49-50. American Numismatic and Archaeological Society. Attic Talent, http://en.wikipedia.org/wiki/Attic_talent. Talent (Measurement), http://en.wikipedia.org/wiki/Talent_ (measurement). Talent (Weight), http://simple.wikipedia.org/wiki/Talent_(weight) and author's calculations.

Table 2. Summary of Cost of Alexander the Great Expedition ( $\Delta \alpha \pi \alpha$ ó $\alpha$ )

\begin{tabular}{|c|c|c|c|c|}
\hline $\begin{array}{l}\text { 1. The Expedition to Asia (336-328 B.C.) Total } \\
\text { 1a. The Expedition to Asia (336-328 B.C.) Salaries } \\
\text { 1b. The Expedition to Asia (336-328 B.C.) Bonuses }\end{array}$ & $\begin{array}{l}\text { 622,172,000 Drs } \\
526,172,000 \text { Drs } \\
96,000,000 \text { Drs }\end{array}$ & \begin{tabular}{|c|}
$95,101,354.480$ ozs \\
$80,427,389.680$ ozs \\
$14,673,964.800$ ozs
\end{tabular} & $\begin{array}{l}\$ 1,784,389,296 \\
\$ 1,509,061,296 \\
\$ 275,328,000\end{array}$ & \begin{tabular}{|l|}
$24.284 \%$ \\
$20.537 \%$ \\
$3.747 \%$
\end{tabular} \\
\hline 2. The Expedition to India (327-323 B.C.) Salaries, etc. & $548,407,600$ Drs & $83,826,185.610$ ozs & $\$ 1,572,832,987$ & $21.405 \%$ \\
\hline 3. Military Equipment and Constructions & $176,267,000$ Drs & $26,943,080.760$ ozs & $\$ 505,533,756$ & $6.880 \%$ \\
\hline 4. Food and Transportation & $688,220,000$ Drs & $105,197,042.200 \mathrm{ozs}$ & $\$ 1,973,814,960$ & $26.862 \%$ \\
\hline 5. Medical Expenses & $31,798,000$ Drs & $4,860,445.135$ ozs & $\$ 91,196,664$ & $1.241 \%$ \\
\hline 6. Indemnities and Veterans & $437,447,000$ Drs & $66,865,436.250$ ozs & $\$ 1,254,597,996$ & $17.074 \%$ \\
\hline 7. Feasts and Social Events & $53,507,050$ Drs & $8,178,755.919$ ozs & $\$ 153,458,219$ & $2.088 \%$ \\
\hline 8. Financial Scandals & $4,200,000$ Drs & $641,985.960$ ozs & $\$ 12,045,600$ & $0.164 \%$ \\
\hline Total & $2,562,018,650$ Drs & $391,614,286.300$ ozs & $\$ 7,347,869,488$ & $100 \%$ \\
\hline
\end{tabular}

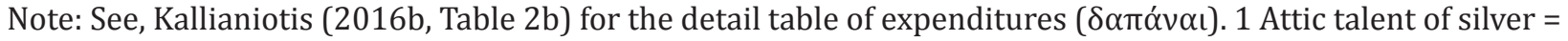
6,000 Drs was the wage of 9 man-years of skilled work (360 days work) $=16.667$ Drs $/$ day $(9$ men $)=1.85185$ Drs/day/skilled worker; or (if the work was 260 days/year) $=23.07692308$ Drs/day (9 men) $=2.564102564$ Drs/day/skilled worker. During the Peloponnesian war: 1 Attic talent of silver (6,000 Drs) was 1 month wages of a trireme crew of 200 men = 200 Drs/day for $200 \mathrm{men}=1 \mathrm{Dr} /$ day/man. 1 Dr/day $=4.3$ grs of silver/day/ rower $=0.151678028$ ozs $(\$ 18.76 / \mathrm{oz})=\$ 2.845 /$ day. 1 Assuming 360 days work $/$ year, 2 Assuming 260 days work/year (by some other authors), 3 During the Peloponnesian war (431-404 B.C.), 4We use for our budget, here, the higher wage (cost) $=1.442$ Drs/day, 5Assuming Parmenion had no ships (there are no information

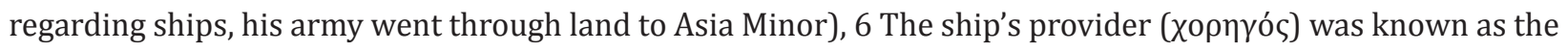
trierarch ( $\tau \rho \iota \mid \rho \alpha \rho \chi o s$, triērarchos). He was a wealthy citizen (usually from the class of the pentakosiomedimnoi ( $\pi \varepsilon v \tau \alpha \kappa о \sigma\llcorner о \mu \varepsilon ́ \delta ц \nu \nu ८)$, responsible for manning, fitting out and maintaining the ship for his liturgical year at least; the ship itself belonged to the city-state (i.e., Athens). The trierarchy ( $\tau \rho ı \rho \alpha \rho \chi i ́ \alpha$, triērarchia) was one 
of the liturgies of ancient Athens; although it afforded great prestige, it constituted a great financial burden, so that in the 4th century B.C., it was often shared by two citizens, and after 397 B.C. it was assigned to special boards. The cost of the ship was one (1) talent or 6,000 Drs per annum. (For this reason, we do not have many information on its cost of construction and maintenance). 7 The winner (Alexander's) casualty was about 15\%. See, http://www.quora.com/How-has-mortality-rate-per-battle-changed-throughout-history. 8 Diodorus. 9The ancient Greek marriage celebration consisted of a three part ceremony which lasted three days: the proaulia, which was the pre-wedding ceremony, the gamos, which was the actual wedding, and the epaulia, which was the post-wedding ceremony.10 It seems a little high (it might include the cost of the horse, too).

Alexander's conquests lasted for 13 years (336-323 B.C.); thus, the budget is for $8+5=13$ years (total).

Source: Diodorus, Justin, Plutarch, Arrian.

Table 3. Revenue (Пó $о$ )

1. Royal Treasury (covered mercenaries) (amount unknown)

2. Gold and silver coins from the Macedonian mines (amount unknown)

3. Revenue from customs, tariffs, and taxes on royal lands (6,000 talents/annum)1: $36,000,000$ Drs or $5,502,736.8$ ozs or $\$ 103,248,000$

4. Loan (short-term):2 1,460 talents or $8,760,000$ Drs or $1,338,999.288$ ozs or $\$ 25,123,680$

5. Aristocracy grants (covered Macedonian army) (amount unknown)

6. Cost of navy was covered from the trierarchy (about 1 talent): 2,310 talents or 13,860,000 Drs or $2,118,553.668$ ozs or $\$ 39,750,480$ (120 ships $\mathrm{x} 1$ talent $\mathrm{x} 13$ years $=1,560$ talents or 9,360,000 Drs or $1,430,711.568$ ozs or $\$ 26,844,480$ ) (Plus 150 ships $x 1$ talent $x 5$ years $=750$ talents or $4,500,000$ Drs or $687,842.1$ ozs or $\$ 12,906,000$ )

7. Taxes (to non-Greek cities in Asia Minor and to foreign cities with hostile attitude) $(9,000$ talents, 311,000 talents, 4 30,000 talents,5 per annum). [We take an average of 17,000 talents/annum (6,000 talents from taxes on royal lands $+11,000$ talents general taxes) $\mathrm{x} 13$ years $=221,000$ talents] or $1,326,000,000$ Drs or $202,684,138.8$ ozs or $\$ 3,802,968,000$

8. Plundering ( $\lambda \alpha \dot{\alpha} \varphi v \rho \alpha$ ) by seizing hostile cities (334 B.C.) in Asia Minor (amount unknown)

9. Darius ransom $(\lambda u ́ \tau \rho \alpha)$ for his family (333 B.C.): 10,000 talents ( $60,000,000$ Drs), which was not accepted and he gave a colossal ransom of 30,000 talents or $180,000,000$ Drs or $27,513,684$ ozs or $\$ 516,240,000$

10. Darius treasure in Susa in 331 B.C. (amount unknown)

11. In 330 B.C., at Ecbatana, Alexander had the amount of $180,000-190,000$ talents 6 or 1,080,000,000$1,140,000,000$ Drs or $165,082,104-174,253,332$ ozs or $\$ 3,097,440,000-\$ 3,269,520,000$ (We take the smaller amount of 180,000 talents).

12. In 330 B.C., at Persepolis (a very prosperous city) that it had a lot of gold and silver, he got: 2,500 tons of gold,7 which was $96,153.84615$ gold talents or $961,538.4615$ silver talents or 5,769,230,769 Drs or $881,848,846.1$ ozs or $\$ 16,546,153,850(2,500,00 \mathrm{kgs}: 26 \mathrm{kgs}=96,153.84615$ talents of gold $\mathrm{x}$ $10=961,538.4615$ silver talents $\times 6,000$ Drs $=5,769,230,769$ Drs)

13. Other sources tell that the total amount of silver bullion captured between 333-330 B.C. was between 180,000 and 400,000 talents of silver (1,080,000,000-2,400,000,000 Drs).

14. Tax and administration reforms to control the vast empire (amount unknown)

15. Alexander retrieve the bulk of the Persian treasure from Ecbatana (324 B.C.) (amount unknown)

Total: (3)+(4)+(6)+(7)+(9)+(11)+(12) $8,413,850,769$ Drs $\quad 1,286,089,063$ ozs $\$ 24,130,924,010$ 
Note: ${ }^{1}$ Pseudo-Aristotle's Oikonomika; ${ }^{2}$ Plutarch; ${ }^{3}$ Herodotos (3.89); ${ }^{4}$ Antigonos Monophthalmos; ${ }^{5}$ Justin (13.1.9); ${ }^{6}$ Diodorus Siculus 17.80.3, Strabo 15.3.9, and Justin 12.1.1; ${ }^{7}$ The gold/silver ratio was $1 / 13$ and due to this huge amount of gold (excess supply) its price fell to $1 / 10$.

Source: Diodorus (17.80.3), Strabo (15.3.9), Justin (12.1.1), Arrian, Curtius, Plutarch.

\section{REFERENCES}

Aelian, “64”, Varia Historia XII .

Aperghis, Makis (2001), "Population-Production-taxation-Coinage: A model for the Seleukid

Economy", in Hellenistic Economies, Zofia H. Archibald et al (ed.), London and New York: Routledge, pp. 69-102.

Archibald, Zofia, John Davies, Vincent Gabrielsen, and G.J. Oliver, ed. (2001), Hellenistic

Economies, London and New York: Routledge.

Aristotle, Athenian Constitution, 10.2

Arrian (1976). de Sélincourt, Aubrey, ed. Anabasis Alexandri (The Campaigns of Alexander).

Penguin Books.

Arrian 1893, 3.1. Chinnock, E. J., ed. Anabasis Alexandri.

Badian, E. (1961). “Harpalus”. The Journal of Hellenic Studies 81: 22. doi:10.2307/628074.

Blois de, Lukas (1997), An Introduction to the Ancient World, UK: Routledge.

Bose, Partha (2003). Alexander the Great's Art of Strategy. Crows Nest, NSW: Allen \& Unwin.

Cohen, E.E. (1992), Athenian Economy and Society: A Banking Perspective, N.J.: Princeton.

Curtius, Quintus Rufus, Historiae Alexandri Magni, (a biography of Alexander in ten books, of which the last eight survive).

Davies, John K. (2011) The Economies of Hellenistic Societies. Archibald, Z.H. and Davies, J.K. and Gabrielsen, V. and Oliver, J.G., eds, Oxford: Oxford University Press.

Davis-Kimball, Jeannine (1995). "The Scythians in southeastern Europe". Nomads of the Eurasian Steppes in the early Iron Age. Zinat press.

Depuydt, L. (1997), “The Time of Death of Alexander the Great: 11 June 323 BC, ca. 4:00-

5:00 pm". Die Welt des Orients 28: 117-35.

Diodorus Siculus (1989). "Library of History”. CH Oldfather, translator. Perseus Project.

Diodorus Siculus (1963). Welles, C. Bradford, ed. Library of History 8. Cambridge,

Massachusetts: Harvard University Press.

Engels, Donald W. (1978), Alexander the Great and the Logistics of the Macedonian Army,

Berkeley and Los Angeles: University of California Press.

Engen, Darel (2004). “The Economy of Ancient Greece”, EH.Net Encyclopedia.

Foreman, Laura (2004). Alexander the conqueror: the epic story of the warrior king. Da Capo

Press. p. 217.

Volume 2016

Page 22 
Gergel, Tania, ed. (2004). The Brief Life and Towering Exploits of History's Greatest Conqueror as Told By His Original Biographers. Penguin.

Green, Peter (2007), Alexander the Great and the Hellenistic Age. London: Phoenix.

Green, Peter (1992), Alexander of Macedon: 356-323 B.C. A Historical Biography. University of California Press.

Grimal, Nicolas (1992). A History of Ancient Egypt (reprint ed.). Blackwell.

Hammond, NGL (1983). Sources for Alexander the Great. Cambridge University Press.

Herodotus 2.143, 6.137, Herodotus, Histories 6.46.1

Herodotus (1998), Robin Waterfield and Carolyn Dewald, The Histories, p. 593.

Hypereides, Against Demosthenes, 1

Justin, The Epitome of the Philippic History of Pompeius Trogus.

Kallianiotis, I.N. (2016a), "Hellenism Prophetic-Orthodoxy Apocalyptic", Christian

Vivliografia, June 15, pp. 1-4. https://christianvivliografia.wordpress.com/2016/06/15/\%ce\%b5\%ce \%bb\%ce\%bb\%ce\%b7\%ce\%bd\%ce\%b9\%cf\%83\%ce\%bc\%e1\%bd\%b8\%cf\%82-\%cf\%80\%cf\%81\% се\%bf\%cf\%86\%ce\%b7\%cf\%84\%ce\%b9\%ce\%ba\%e1\%bd\%b8\%cf\%82-\%e1\%bd\%80\%cf\%81\%ce \%b8\%ce\%bf\%ce\%b4\%ce\%bf\%ce\%be\%ce\%af\%ce\%b1-\%e1\%bc\%80/

Kallianiotis, I.N. (2016b), "The Economic History of Alexander the Great Expedition”, International Journal of Economics and Financial Research, Vol. 2, No. 2, February, pp. 16-32.

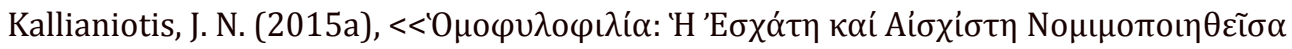
A $\mu \alpha \rho \tau i ́ \alpha>>$, Christian Vivliografia, December 31, pp. 1-2.

Kallianiotis, I.N. (2015b), "Economic Policy of Alexander the Great”, unpublished manuscript, University of Scranton, June, pages 72.

Kallianiotis, John N. (2013a), Exchange Rates and International Financial Economics: History, Theories, and Practices, New York, N.Y.: Palgrave MacMillan.

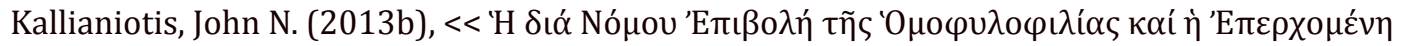

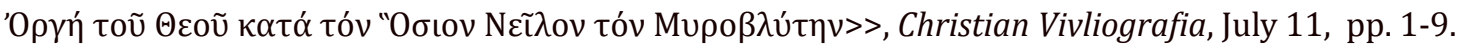

Kallianiotis, John N. (2010), "An Archaeological Perspective of the Macedonian Question",

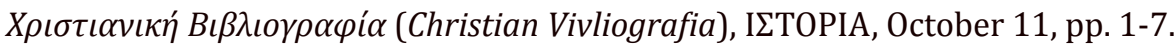

Kallianiotis, John N. (1992), Hellas: A Swift Historical Journey and the Macedonian Question, Hellenic Orthodox Church of the Annunciation, Scranton, PA, U.S.A.

Kingsley, Bonnie M. (1986). "Harpalos in the Megarid (333-331 B.C.) and the Grain Shipments from Cyrene (S.E.G. IX $2+$ = Tod, Greek Hist. Inscr. II No. 196)". Zeitschrift für Papyrologie und Epigraphik 66: 165.

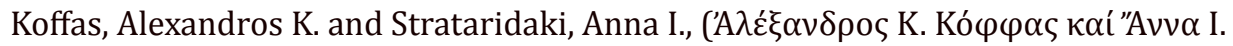

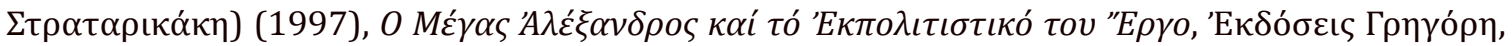
'A

Kosmetatou, Elizabeth (1998). "The Location of the Tomb: Facts and Speculation”. Greece.org. Archived from the original on 31 May 2004. Retrieved 16 December 2011. 
Kostopoulos, Dimitrios (2012), "The economics of Alexander the Great", Archaeology News Network.http://archaeologynewsnetwork.blogspot.com/2012/12/alexander-great-verycompetent-expert.html\#.VJMvxaMo6M8

Lane Fox, Robin (1973), Alexander the Great, Penguin.

Lendering, Jona (2007), “Alexander the Great: His Towns”, Livius.org, webpage: Livius-alex-z2.

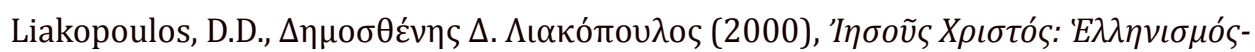

Х

Marchant, E.C. and O.J. Todd (1997), Xenophon: Memorabilia, Oeconomicus, Symposium, Apology, Cambridge, Massachusetts: Harvard University Press.

Morkot, Robert (1996). The Penguin Historical Atlas of Ancient Greece. Penguin.

Nelson Frye, Richard (1984). The History of Ancient Iran, Part 3, Volume 7. C.H.Beck. pp. 9-15.

Plutarch, Parallel Lives and Moralia. Plutarch's Life of Alexander.

Plutarch (Plutarch) (1919), Perrin, Bernadotte, ed. Plutarch, Alexander. Perseus Project.

Plutarch (1936). Babbitt, Frank Cole, ed. On the Fortune of Alexander IV. Loeb Classical Library.

pp. 379-487.

"Plutarch". Oxford Dictionary of Philosophy.

Polybius, The Histories or The Rise of the Roman Empire by Polybius: At Perseus Project:

English \& Greek version

Polybius; Paton, W.R. (Translator) (2012). Polybius: The Histories. The Loeb Classical Library

(in Ancient Greek, English, and Latin). Chicago: University of Chicago (LacusCurtius).

Polybius; Paton, W.R. (Translator) (1922-1927). Polybius: The Histories. The Loeb Classical

Library (in Ancient Greek, English, and Latin). London; New York: William Heinemann; G.P. Putnam's Sone.

Ring, Trudy, Robert M. Salkin, K.A. Berney, Paul E. Schellinger, eds. (1994). International

Dictionary of Historic Places. Chicago: Fitzroy Dearborn, 1994-1996.

Roisman, Joseph and Ian Worthington (2010). A Companion to Ancient Macedonia. New York, N.Y.: John Wiley \& Sons.

Rostovtzeff, M.I. (1953), The Social and Economic History of the Hellenistic World, $2^{\text {nd }}$ Impression revised by P.M. Fraser, I-III, Oxford.

Saunders, Nicholas (2007). Alexander's Tomb: The Two-Thousand Year Obsession to Find the Lost Conquerer. Basic Books.

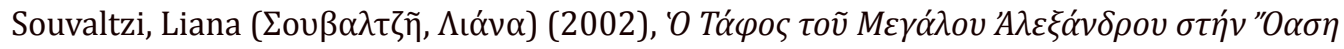

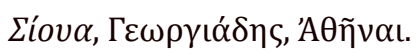

Speck, Henry (2002), "Alexander at the Persian Gates. A Study in Historiography and

Topography", American Journal of Ancient History, 1 (1), pp. 15-234.

Talent (Biblical Hebrew), Unit of Measure, unitconversion.org.

Temin, Peter (2013), The Roman Market Economy, Princeton: Princeton University Press. 
http://encore.scranton.edu/iii/encore/record/C__Rb1937924__STemin.\%20Peter__P0\%2C3_ Orightresult_X4;jsessionid=219B85E7C7996A1081472C05D0B2CD9A?lang=eng\&suite=cobalt

Thucydides, History of the Peloponnesian War 1.117

Thucydides, 2.65.

Torr, Cecil (1906), “Triremes”, The Classical Review, Vol. 20, No. 2, March, p. 137.

Van De Mieroop, Marc (2014), "Silver as a Financial Tool in Ancient Egypt and Mesopotamia", in Ex p la i n ing Monetary and Financial Innovation: A Historical Analysis, edited by Peter Bernholz and Roland Vaubel, Cham: Springer.

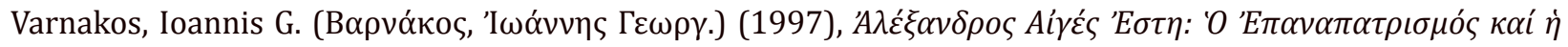

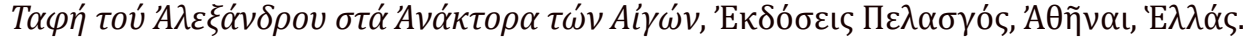

Von Reden, Sitta (2007), Money in Ptolemaic Egypt: From the Macedonian Conquest to the End of the Third Century BC, Cambridge: Cambridge University Press.

Wasson, Donald L. (2014), The Army of Alexander the Great. http://www.ancient.eu/article/676/

Whitehead, D. (1977), The Ideology of the Athenian Metic, Cambridge.

Worthington, Ian (2003). Alexander the Great: A Reader. Routledge. p. 332.

Citation: Dr. Ioannis N. Kallianiotis, "The Management of Expenditures and Revenue by Alexander the Great During his Expedition to the Boundless Asia". American Research Journal of Business and Management, Volume 2016; pp:1-25

Copyright (C) 2016 Dr. Ioannis N. Kallianiotis, This is an open access article distributed under the Creative Commons Attribution License, which permits unrestricted use, distribution, and reproduction in any medium, provided the original work is properly cited. 